\title{
Ground Snow Loads for New Hampshire
}

Wayne Tobiasson, James Buska, Alan Greatorex,

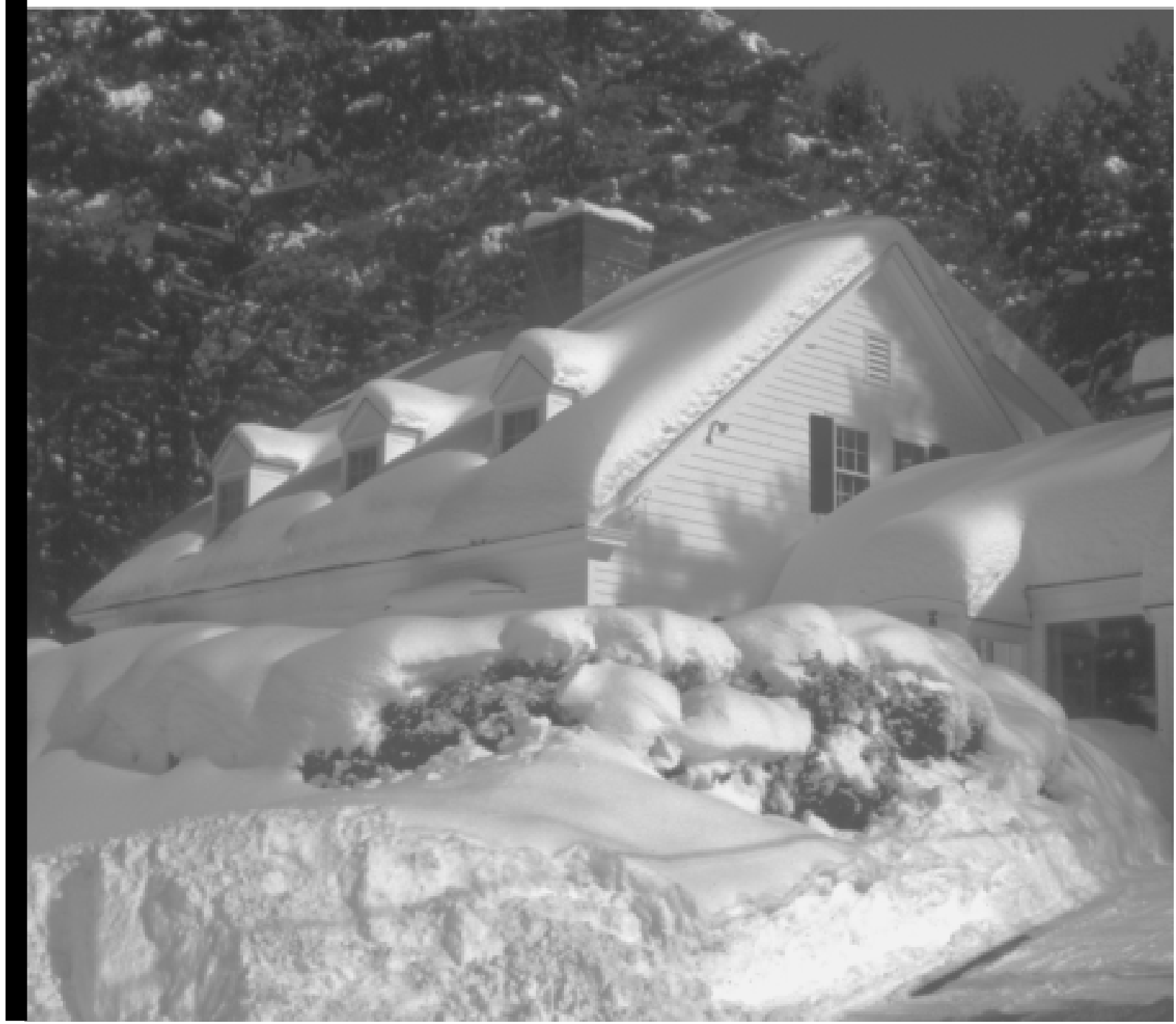


Abstract: Because of New Hampshire's hilly landscape, mapped values of ground snow load are not available for much of its area. We conducted snow load case studies to establish ground snow loads for a specific elevation in each of the 259 towns in the state. That work was done by three researchers and three structural engineers practicing in New Hampshire. While our methods of analysis varied somewhat, our results were comparable and the feedback we received from each other was quite valuable. We also established a statewide elevation adjustment factor to transfer our snow load answers to other elevations in each town. We suggest that similar studies be conducted for other places in the United States where mapped values are not available because of extreme local variations in ground snow loads.

This project has been a collaborative effort by the Structural Engineers of New Hampshire (SENH) and the U.S. Army Cold Regions Research and Engineering Laboratory (CRREL).
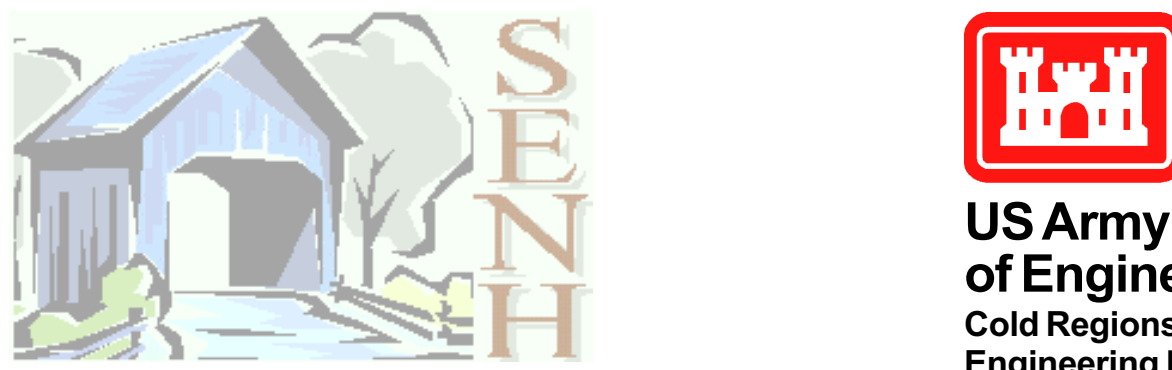

US Army Corps of Engineers ${ }_{\circledast}$

Cold Regions Research \& Engineering Laboratory

How to get copies of ERDC technical publications:

Department of Defense personnel and contractors may order reports through the Defense Technical Information Center:

DTIC-BR SUITE 0944

8725 JOHN J KINGMAN RD

FT BELVOIR VA 22060-6218

Telephone (800) 225-3842

E-mail help@dtic.mil msorders@dtic.mil

WWW http://www.dtic.mil/

All others may order reports through the National Technical Information Service:

NTIS

5285 PORT ROYAL RD

SPRINGFIELD VA 22161

Telephone (703) 487-4650

(703) 487-4639 (TDD for the hearing-impaired)

E-mail_orders@ntis.fedworld.gov

WWW http://www.ntis.gov/index.html

For information on all aspects of the Engineer Research and Development Center, visit our World

Wide Web site:

http://www.erdc.usace.army.mil 


\section{Technical Report ERDC/CRREL TR-02-6}

\section{Ground Snow Loads for New Hampshire}

Wayne Tobiasson, James Buska, Alan Greatorex, Jeff Tirey, Joel Fisher, and Steve Johnson
February 2002 


\section{PREFACE}

This report was prepared by Wayne Tobiasson, P.E., Research Civil Engineer (retired volunteer); James Buska, Research Civil Engineer; and Alan Greatorex, Civil Engineering Technician of the Civil and Infrastructure Engineering Branch, Cold Regions Research and Engineering Laboratory (CRREL), Engineering Research and Development Center (ERDC), U.S. Army Corps of Engineers; and Jeff Tirey, P.E., Structural Engineer; Joel Fisher, P.E., Structural Engineer; and Steve Johnson, P.E., Structural Engineer of Structural Engineers of New Hampshire Inc. (SENH). SENH is a non-profit professional association of structural engineers. Mr. Tirey is a principal of Tirey and Associates, P.C. of Littleton, NH; Mr. Fisher is a Manager, Structural Engineering, with Rist-FrostShumway Engineering of Laconia, NH; and Mr. Johnson is a Structural Engineer with Vanasse Hangen Brustlin Inc. of Bedford, NH.

The authors thank George Blaisdell and Kathy Jones of CRREL for their reviews and comments on this report.

This work was sponsored by the U.S. Army Corps of Engineers, the New Hampshire Building Code Officials Association, and the following New Hampshire structural engineering firms:

- Altus Engineering

- CLD Consulting Engineers Inc.

- Emanuel Engineering

- H.E.B. Civil Engineers P.A.

- H.L.Turner Group

- Hayashi Corporation

- Hoyle, Tanner and Associates

- JSN Associates

- McFarland-Johnson, Inc.

- Rist-Frost-Shumway Engineering

- SEA Consultants

- Stahlman Engineering Corporation 
- Steffensen Engineering

- Tirey and Associates, P.C.

About $60 \%$ of the work reported here was done on a volunteer basis.

Renee Melendy and Arlene Phillips of CRREL compiled our case study answers in such a way that the author of each value and comment was unknown to the rest of us.

The contents of this report are not to be used for advertising or promotional purposes. Citation of brand names does not constitute an official endorsement or approval of the use of such commercial products. 


\section{CONTENTS}

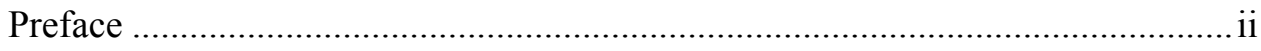

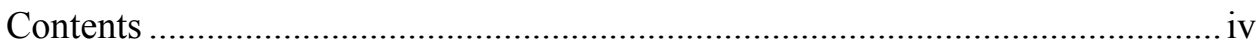

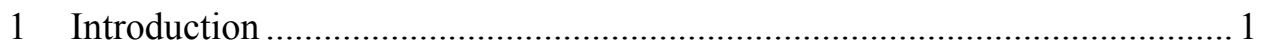

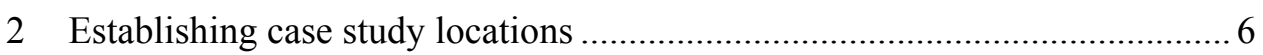

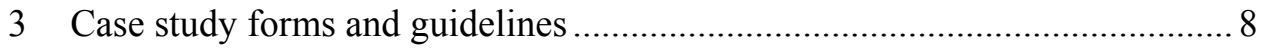

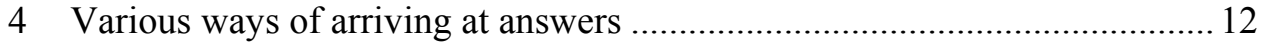

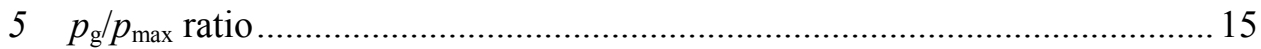

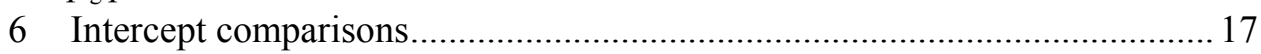

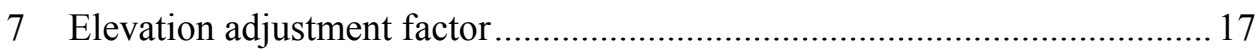

8 One load and one elevation correction factor for all of New Hampshire? .... 18

9 Modification of case study tabulations and plots ......................................... 19

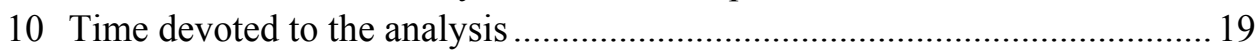

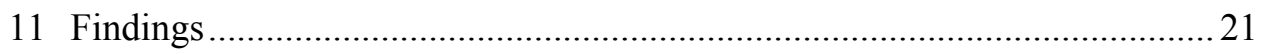

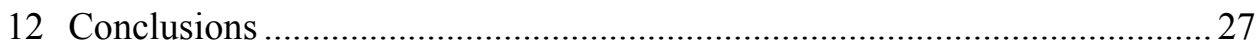

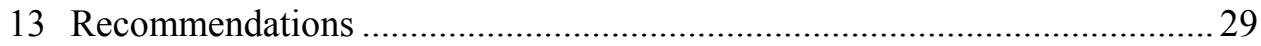

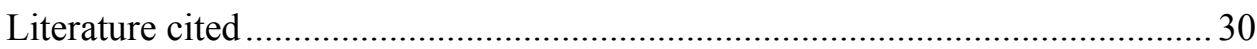

Appendix A. Coordinates of the geographical center and elevation information for each town in New Hampshire............................. 31

Appendix B. Guidelines on conducting case studies......................................... 37

\section{ILLUSTRATIONS}

Figure 1. State of New Hampshire, showing town and county boundaries overlaid with the ground snow load information in ASCE 7 ............... 3

Figure 2. State of New Hampshire, showing stations where ground snow load information is available for our three categories of towns. .......... 4

Figure 3. Case study data tabulation for the town of Salisbury ........................... 9

Figure 4. Case study plots for the town of Salisbury ....................................... 10

Figure 5. Nearest-values plot for Randolph, showing the adverse effect of Mt. Washington on the slope of the line of best fit ......................... 11

Figure 6. Log-normal probability plots for Waterville Valley, Milford,

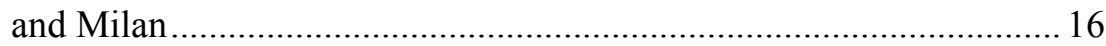

Figure 7. Elevation adjustment factor for the 236 highest-quality stations

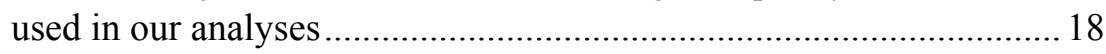

Figure 8. Location of each New Hampshire town presented in Table 1.............22

\section{TABLES}

Table 1. Ground snow load $\left(p_{\mathrm{g}}\right)$ at a specific elevation for all

New Hampshire towns. 


\title{
Ground Snow Loads for New Hampshire
}

\author{
WAYNE TOBIASSON, JAMES BUSKA, ALAN GREATOREX, JEFF TIREY, \\ JOEL FISHER, AND STEVE JOHNSON
}

\section{INTRODUCTION}

Determining appropriate snow loads is a critical step in the design of structures in cold regions. Because of New Hampshire's hilly terrain, there are extreme local variations in snow loads, and mapped values are not available in codes and standards for much of the state. In such areas the selection of an appropriate snow load is left to the authority having jurisdiction. In most cases such authorities know little about snow loads. Errors and inconsistencies result, which jeopardize public safety.

These problems prompted CRREL and Structural Engineers of New Hampshire Inc. (SENH) to work together to generate snow load values for all locations in the state except for a few high-elevation places.

For the design of structures in the United States, the primary resource document used by various building codes is American Society of Civil Engineers (ASCE) Standard 7, "Minimum design loads for buildings and other structures" (ASCE 2000). It is commonly referred to as ASCE 7-98. It is revised and reissued every few years. The next edition will be referred to as ASCE 7-02. The first step in determining design snow loads is to determine the ground snow load at the place of interest. ASCE 7-98 contains a map of the United States overlaid with that information. That map was made by Tobiasson and Greatorex of CRREL using data from 204 "first-order" National Weather Service (NWS) stations, where snow depths and snow loads are measured frequently, and data from about 11,000 other NWS "co-op" stations, where only the depth of snow on the ground is measured frequently. In some areas, extreme local variations in ground snow loads preclude mapping at a national scale. In those areas the national map contains the designation "CS" instead of a value. CS indicates that case studies are required to establish ground snow loads in these areas. In other areas the values presented on the map only apply up to certain elevations, which are shown in parentheses. Case studies are also required above such elevations. 
Figure 1 presents the information from the ASCE 7-98 map for New Hampshire, showing county and town boundaries. The word "town," as used here, represents both incorporated towns and other unincorporated places. In total these 259 towns cover all of New Hampshire's land. The zoned values in Figure 1 are ground snow loads with a $2 \%$ annual probability of being exceeded (i.e., they represent a 50-year mean recurrence interval). As can be seen in Figure 1, all of New Hampshire is either in a "CS" area or the zoned values have elevation limits (the numbers in parentheses) above which case studies are needed. Thus, case studies are needed to determine ground snow loads for many structures in New Hampshire. Section 7.2, "Ground Snow Loads, $\mathrm{p}_{\mathrm{g}}$," of ASCE 7-98 requires that, in these situations, ground snow loads "shall be based on an extreme value statistical analysis of data available in the vicinity of the site using the value with a $2 \%$ annual probability of being exceeded (50-year mean recurrence interval)."

At CRREL a methodology has been developed to conduct snow load case studies. It and the data used are described in the paper, "Database and methodology for conducting site specific snow load case studies for the United States," which was presented at the Third International Conference on Snow Engineering (Tobiasson and Greatorex 1997). That database also contains information from an additional 3300 locations across the United States where ground snow loads are measured a few times each winter by other agencies and companies. These are referred to as "non-NWS" stations.

Figure 2 shows New Hampshire overlaid with town boundaries and the location of each station in the database used to perform case studies in New Hampshire. There are 1 NWS "first-order" station, 89 NWS "co-op" stations, and 91 "non-NWS" stations in New Hampshire. First-order stations in adjacent states within 50 miles $(80 \mathrm{~km})$ of the border and other stations within 25 miles $(40 \mathrm{~km})$ of the border were also used in our analysis. They are also shown in Figure 2. In total, 388 stations were available, of which 4 were NWS "first-order" stations; 192 were NWS "co-op" stations; and 192 were "non-NWS" stations. Of these stations, 302 had enough data to allow calculation of 50-year ground snow loads.

SENH is a nonprofit professional association of structural engineers. Several SENH members were concerned that the lack of definitive ground snow load guidance for much of New Hampshire was resulting in inconsistent design criteria. They felt that many engineers and local code officials did not know appropriate values. In a survey SENH conducted in 1995, 68\% of the 220 towns that responded to the survey said they required, as a minimum, the value presented in the 1993 BOCA Code (BOCA 1993). However, over $80 \%$ of New Hampshire towns were in a blacked-out area of the snow load map in that code. 


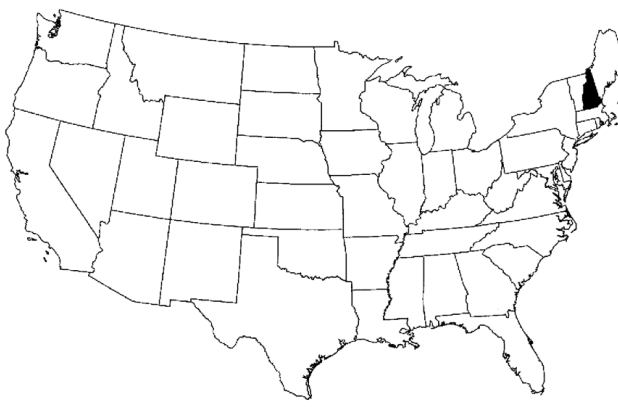

Numbers in parentheses represent the upper elevation limits in feet for the ground snow load values presented alongside. Site-specific case studies are required to establish ground snow loads at higher elevations not covered.

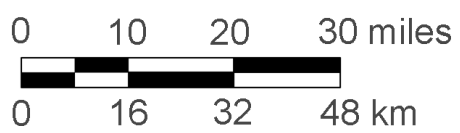
\{ 


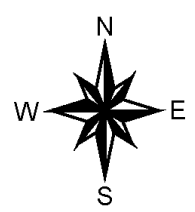

\begin{tabular}{|l|l|}
\hline & \begin{tabular}{l} 
Towns, all or a part of which lie within the "CS" \\
zone in the ASCE-7 snow load map (140 towns \\
\hline
\end{tabular} \\
\hline & $\begin{array}{l}\text { Heavily forested areas with few structures, } \\
\text { all within the "CS" zone (17 towns) } \\
\text { snow load map up to an elevation limit (102 tov }\end{array}$ \\
& NWS "First-Order" Stations (4) \\
& NWS "Co-op" Stations (192) \\
"Non-NWS" Stations (192)
\end{tabular}

zone in the ASCE-7 snow load map (140 towns)

\begin{tabular}{|l|l|l|}
\hline & $\begin{array}{l}\text { Towns, all or a part of which lie within the "c } \\
\text { zone in the ASCE-7 snow load map (140 to } \\
\text { Heavily forested areas with few structures, } \\
\text { all within the "CS" zone (17 towns) }\end{array}$ \\
$\begin{array}{l}\text { Towns for which a value is available on the } \\
\text { snow load map up to an elevation limit (10? }\end{array}$ \\
NWS "First-Order" Stations (4) \\
NWS "Co-op" Stations (192) \\
"Non-NWS" Stations (192)
\end{tabular}

\begin{tabular}{|l|l|}
\hline & $\begin{array}{l}\text { Towns, all or a part of which lie with } \\
\text { zone in the ASCE-7 snow load mar }\end{array}$ \\
\hline & $\begin{array}{l}\text { Heavily forested areas with few str } \\
\text { all within the "CS" zone (17 towns) }\end{array}$ \\
\hline & $\begin{array}{l}\text { Towns for which a value is availabl } \\
\text { snow load map up to an elevation I }\end{array}$ \\
NWS "First-Order" Stations (4) \\
NWS "Co-op" Stations (192) \\
"Non-NWS" Stations (192)
\end{tabular}

Towns for which a value is available on the ASCE-7

snow load map up to an elevation limit (102 towns)

\begin{tabular}{|l|l|l|}
\hline & $\begin{array}{l}\text { Towns, all or a part of which lie } \\
\text { zone in the ASCE-7 snow load } \\
\text { Heavily forested areas with few } \\
\text { all within the "CS" zone (17 tow }\end{array}$ \\
\hline $\begin{array}{l}\text { Towns for which a value is avai } \\
\text { snow load map up to an elevati }\end{array}$ & $\begin{array}{l}\text { NWS "First-Order" Stations (4) } \\
\text { NWS "Co-op" Stations (192) }\end{array}$ \\
"Non-NWS" Stations (192)
\end{tabular}

\begin{tabular}{|l|l|}
\hline & \begin{tabular}{l} 
Towns, all or a part of which li \\
zone in the ASCE-7 snow loa \\
\hline
\end{tabular} \\
\hline & $\begin{array}{l}\text { Heavily forested areas with fe } \\
\text { all winin the "CS" zone (17 to }\end{array}$ \\
\hline & $\begin{array}{l}\text { Towns for which a value is av } \\
\text { snow load map up to an eleve } \\
\text { NWS "First-Order" Stations ( }\end{array}$ \\
NWS "Co-op" Stations (192) & "Non-NWS" Stations (192)
\end{tabular}

\begin{tabular}{|l|l|}
\hline & $\begin{array}{l}\text { Towns, all or a part of which I } \\
\text { zone in the ASCE-7 snow loa } \\
\text { Heavily forested areas with fe } \\
\text { all within the "CS" zone (17 to }\end{array} \quad \begin{array}{l}\text { Towns for which a value is a } \\
\text { snow load map up to an elev } \\
\text { NWS "First-Order" Stations }\end{array}$ \\
NWS "Co-op" Stations (192) \\
"Non-NWS" Stations (192)
\end{tabular}
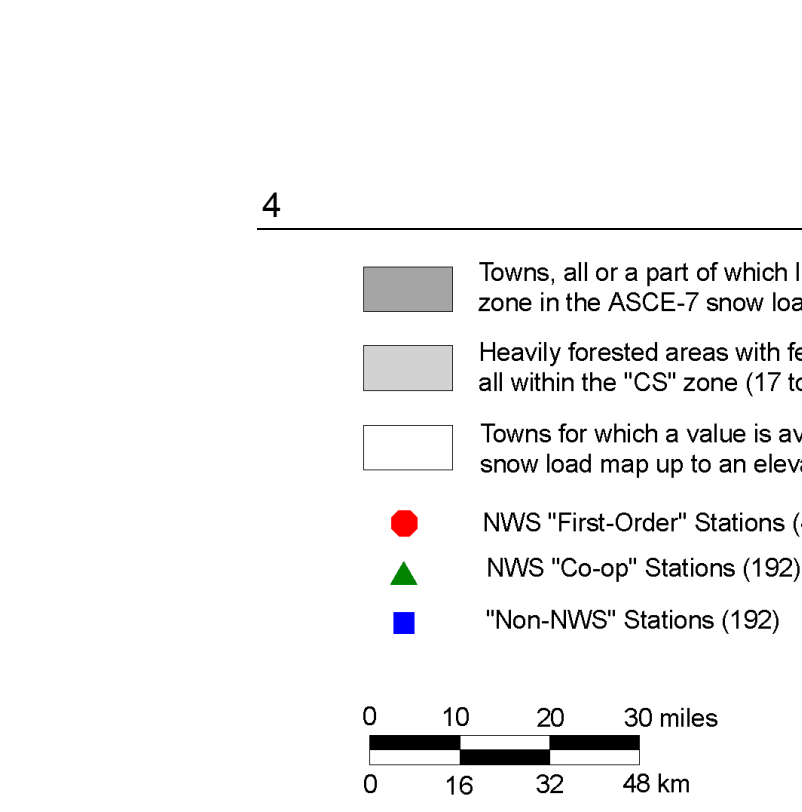

(a)

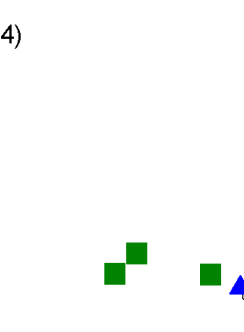

." $\triangle$

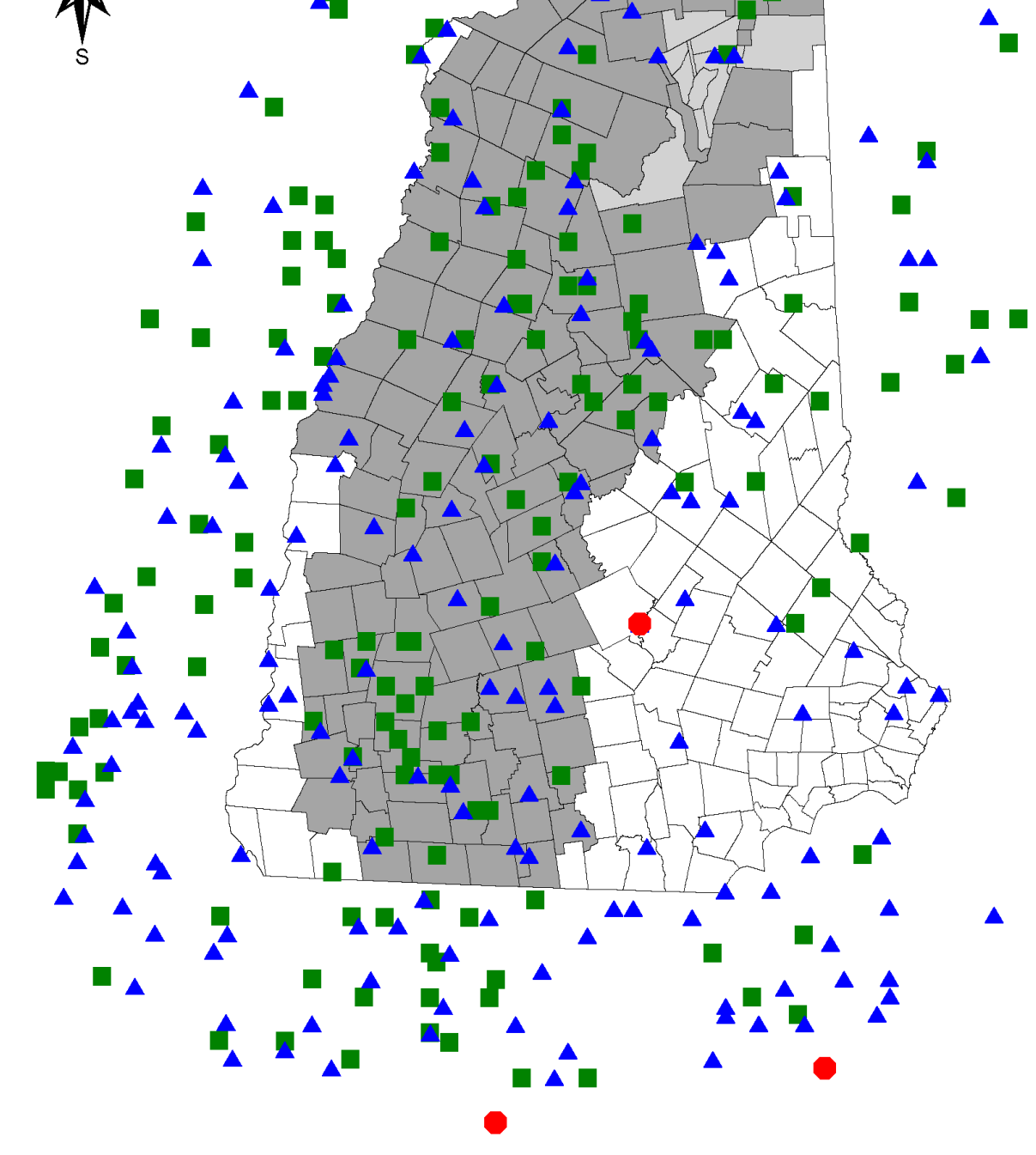

Figure 2. State of New Hampshire, showing stations where ground snow load information is available for our three categories of towns. 
That map is an older version of the national snow load map in ASCE 7-98. It was also made by CRREL. In blacked-out areas of that map, no values are given because "extreme local variations in snow loads preclude mapping at this scale." Clearly, many of those who responded did not know they were located in areas where no ground snow load was provided by the 1993 BOCA Code. When ground snow loads are not available on that map, that code indicated that such loads "shall be determined by the local jurisdiction requirements." The SENH survey revealed that the manner in which such determinations were being made was inconsistent, and little or no technical evidence was available to support the values being used. Several SENH structural engineers felt that, for certain towns, design values were too low, and consequently, inappropriately high risks were being taken by some structural engineers and by the general public.

SENH members expressed interest in using the CRREL database and methodology to develop ground snow loads for each town in New Hampshire. Several volunteered their time to conduct case studies. All prior case studies had been done by two or three CRREL personnel familiar with the database and methodology. To see how well the methodology could be used by others to determine ground snow loads, CRREL personnel trained five practicing licensed SENH engineers in the case study methodology, and 20 case studies were done independently by the two groups.

This pilot study showed that comparable results could be achieved when the groups shared ideas. CRREL and SENH then entered into a Cooperative Research and Development Agreement (CRDA) to determine ground snow loads for 140 New Hampshire towns in the "CS" zone of the snow load map in the 1995 edition of ASCE Standard 7 (i.e., ASCE 7-95). The same snow load map is in ASCE 7-95 and ASCE 7-98 and will be in ASCE 7-02. These towns are shown with dark shading in Figure 2. Seventeen other "towns" in that zone in portions of the White Mountain National Forest, where little or no construction is to be expected, were not studied. These 17 "towns" are shown with light shading in Figure 2.

When we began this CRDA, we chose not to do case studies for the remaining 102 towns where, as shown in Figure 1, ground snow load values up to a limiting elevation were available on the snow load map in ASCE 7-95. The likelihood of obtaining somewhat better values when sites are studied in detail is acknowledged in Section C7.2 of the Commentary to ASCE Standard 7, which indicates that "Detailed study of a specific site may generate a design value lower than that indicated by the generalized national map. It is appropriate in such a situation to use the lower value established by the detailed study. Occasionally a detailed study may indicate that a higher design value should be 
used than the national map indicates. Again, results of the detailed study should be followed."

After completing our study of 140 towns, we did case studies for 6 of the remaining 102 towns as a test. Our case study answers, used with an "elevation adjustment factor," should be better than the mapped values. Based on the results of our six-town test we concluded that they were. Thus, we increased the scope of our initial study of 140 towns to 259 towns and thereby covered every "town" in the state.

\section{ESTABLISHING CASE STUDY LOCATIONS}

The elevation of New Hampshire land varies from sea level along its short coastline to $6,288 \mathrm{ft}(1917 \mathrm{~m})$ at the summit of Mount Washington, which is the highest point of land east of the Mississippi River in the northern half of the United States. Relative to the mountains of the American West, many of which have summit elevations exceeding 14,000 ft (over 4,000 m), Mount Washington is not high. However, what it lacks in elevation, it more than makes up for in meanness, as it is the place where the strongest winds on earth have been recorded. Those winds peaked at $231 \mathrm{mph}(103 \mathrm{~m} / \mathrm{s})$. The White Mountains of New Hampshire are well known by climbers, hikers, and skiers, as are New Hampshire's picturesque villages, rolling farmland, and forests. Few buildings exist in New Hampshire at elevations exceeding 2,500 ft (762 m).

United States Geological Survey (USGS) 1:24,000-scale (1:25,000 when metric) topographic maps of the state were used to determine the coordinates of the geographical center, not the population center, of each town to the nearest minute of latitude and longitude. The case study was conducted there.

Town names are those used by USGS. Some differences exist on other maps and tabulations. They are slight variations except for Livermore, which is also known as "Unorganized Territory."

The USGS maps show topography, town boundaries, roads, and buildings. We did not use the elevation of the geographical center as the case study elevation but, instead, determined six elevations for each town: (1) lowest land; (2) lowest building; (3) lower limit of most buildings; (4) upper limit of most buildings; (5) highest building; and (6) highest land. Significant elevation differences exist within most towns, as shown in Appendix A, which summarizes the information we obtained from the USGS "quad sheets" for each town. 
We chose an elevation near the upper limit of most buildings as our case study elevation to encompass most construction. Usually we rounded down to the nearest $100 \mathrm{ft}(30.5 \mathrm{~m})$, occasionally somewhat more. However, when the difference in elevation between the upper and lower limits of most buildings was only a few hundred feet (about $100 \mathrm{~m}$ ), we rounded up. Had we done these case studies at lower elevations, failure to apply the elevation adjustment factor would have resulted in inappropriately low design loads for some of the buildings in each town. We reasoned that by providing a single value at a relatively high elevation, such a mistake would result in over-design rather than an unsafe structure.

The case study elevation for each town is also presented in Appendix A. Since much higher ground was present in most towns than is represented by our database, an upper limit on elevation was needed for any ground snow loads developed.

Summary statistics for the elevation information in Appendix A are at the end of that appendix. The minimum, median, average, and maximum case study elevations for these New Hampshire towns are 50, 1000, 1030, and $2500 \mathrm{ft}$, respectively. Some land in 75 of the 259 towns is higher than $2500 \mathrm{ft}(762 \mathrm{~m})$. In 8 of those towns, buildings currently exist above $2500 \mathrm{ft}$.

Prior case studies done at CRREL had indicated that design snow loads in northern New England increase, on average, by $2.0-2.5 \mathrm{lb} / \mathrm{ft}^{2}$ for every 100 feet $\left(0.31-0.39 \mathrm{kN} / \mathrm{m}^{2}\right.$ for every $\left.100 \mathrm{~m}\right)$ of increase in elevation. With the "buildable" elevation range in many towns in excess of $500 \mathrm{ft}(152 \mathrm{~m})$ [and in some towns in excess of $1000 \mathrm{ft}(305 \mathrm{~m})$ ], it was evident that a single value, appropriate for use at the higher buildable elevations in a town, would result in significant overdesign at lower elevations. For example, for a town with a $700-\mathrm{ft}$ (215-m) elevation difference between the maximum and minimum buildable elevations, over-design at the lower buildable elevations would be $14-17.5 \mathrm{lb} / \mathrm{ft}^{2}(0.67-0.84$ $\mathrm{kN} / \mathrm{m}^{2}$ ). Thus, we decided to use an elevation adjustment factor to adjust our answer at the case study elevation for each town to other elevations in that town.

Another reason that argued for the introduction of an elevation adjustment factor and an upper limit on elevation was the ever-rising maximum buildable elevation in many towns as development proceeds up hillsides.

Thus, for each town we did not generate a single ground snow load for all places in that town; instead we generated a value at an elevation above that of most building sites that would be adjusted to other elevations in that town using an elevation adjustment factor. 


\section{CASE STUDY FORMS AND GUIDELINES}

Case study forms were computer-generated for each town. Figures 3 and 4 present such forms for the town of Salisbury. The data available in the vicinity are tabulated on the first page or two as shown in Figure 3. For many towns, that tabulation contains data from neighboring states. For Salisbury, periods of record range from 4 to 44 years; about half the information is from NWS first-order and co-op stations and half is from non-NWS stations. Ground snow loads are available in the vicinity at elevations from 350 to $1500 \mathrm{ft}$ (107 to $457 \mathrm{~m})$, bracketing the $900-\mathrm{ft}$ (274-m) elevation chosen for the Salisbury case study.

The final page of each case study (Fig. 4) contains two plots of ground snow load $\left(p_{\mathrm{g}}\right)$ vs. elevation. The upper plot (called the "nearest values" plot) contains just the data from the nearest six to nine stations, while the lower plot (called the "all values" plot) contains all the data available within a 25 - to 30 -mile (40- to $48-\mathrm{km})$ radius, plus any NWS first-order data within 50 miles $(80 \mathrm{~km})$. As shown in Figure 4, the elevation of interest is highlighted on each plot as a dark vertical line. Each plot also contains a straight line of best fit using least squares. The ground snow load where the line of best fit crosses the elevation of interest is shown in a box to the right of each plot. For some towns that ground snow load is similar on the two plots, but for other towns it is quite different. Salisbury was chosen to show how much the two plots could vary. For most towns the two plots are not as different as those of Salisbury.

In the Northeast, ground snow loads generally increase with increasing elevation up to the treeline. Above the treeline they may decrease because of wind action. The straight line of best fit in the nearest-values plot in Figure 4 has a negative slope (i.e., elevation adjustment factor) of $-1.7 \mathrm{lb} / \mathrm{ft}^{2}$ per $100 \mathrm{ft}(-0.26$ $\mathrm{kN} / \mathrm{m}^{2}$ per $100 \mathrm{~m}$ ). The few data points on this nearest-values plot result in an unrealistic slope, so the ground snow load answer of $68 \mathrm{lb} / \mathrm{ft}^{2}\left(3.3 \mathrm{kN} / \mathrm{m}^{2}\right)$ is not to be trusted. The all-values plot in Figure 4 contains enough data points to generate a physically more realistic slope of $2.5 \mathrm{lb} / \mathrm{ft}^{2}$ per $100 \mathrm{ft}\left(0.39 \mathrm{kN} / \mathrm{m}^{2}\right.$ per $100 \mathrm{~m}$ ) and thus a more believable ground snow load of $80 \mathrm{lb} / \mathrm{ft}^{2}\left(3.8 \mathrm{kN} / \mathrm{m}^{2}\right)$, which is our case study answer at an elevation of $900 \mathrm{ft}(274 \mathrm{~m})$ for Salisbury.

Data from near the 6288-ft (1917-m) summit of Mt. Washington created problems. The tabulated ground snow load there is only $56 \mathrm{lb} / \mathrm{ft}^{2}\left(2.7 \mathrm{kN} / \mathrm{m}^{2}\right)$, which is far below the ground snow load at many other places at elevations below $1000 \mathrm{ft}(305 \mathrm{~m})$. The high winds on that treeless summit result in ground snow load measurements that are much too low to be used for our purposes. The lines of best fit on several plots containing the Mt. Washington value have negative slopes. Figure 5 shows how the Mt. Washington value adversely 


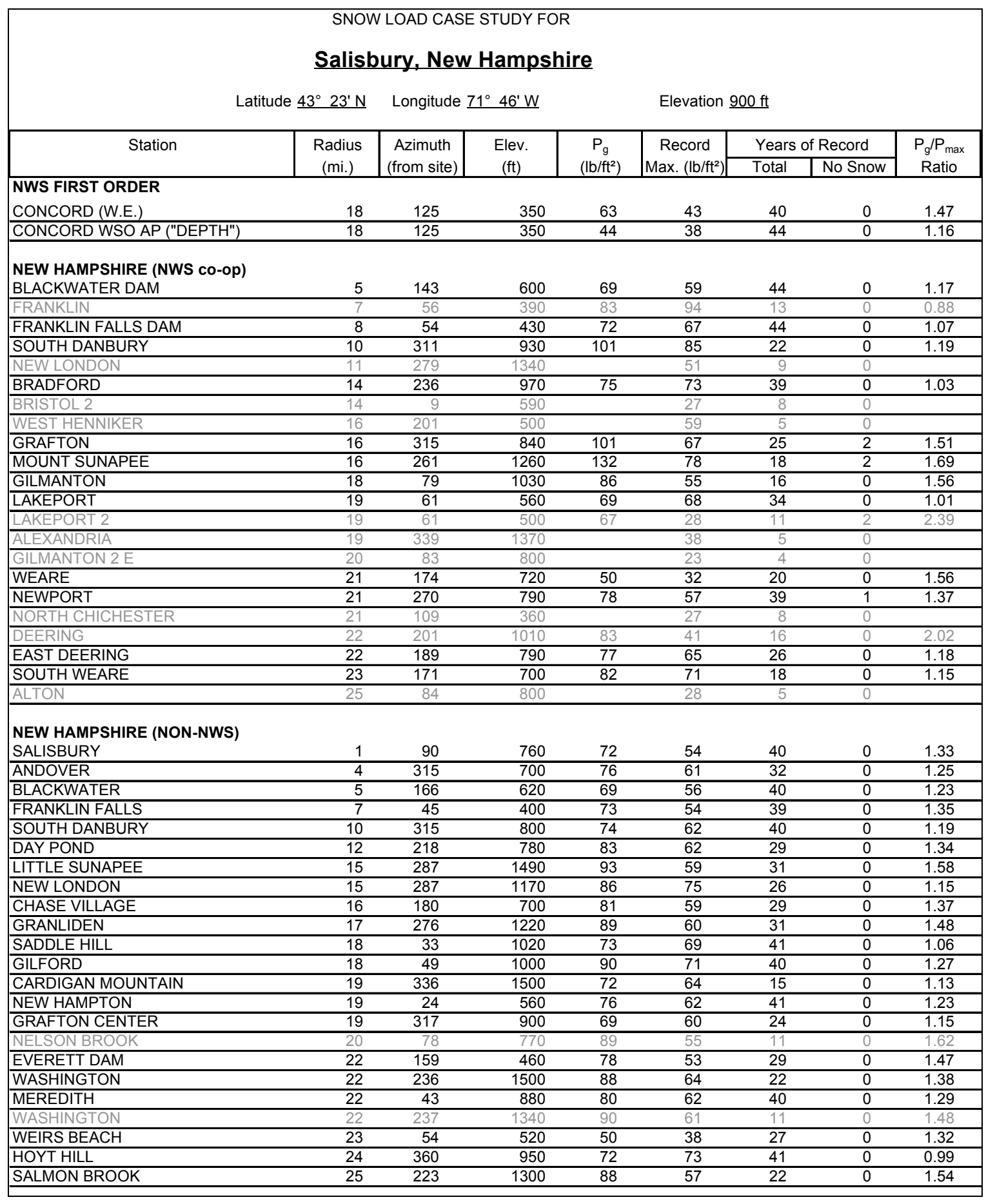

Figure 3. Case study data tabulation for the town of Salisbury. (To convert $\mathrm{lb} / \mathrm{ft}^{2}$ to $\mathrm{kN} / \mathrm{m}^{2}$, multiply by 0.048 ; for miles to km, multiply by 1.61 ; for $\mathrm{ft}$ to $\mathrm{m}$, multiply by 0.305 .) 


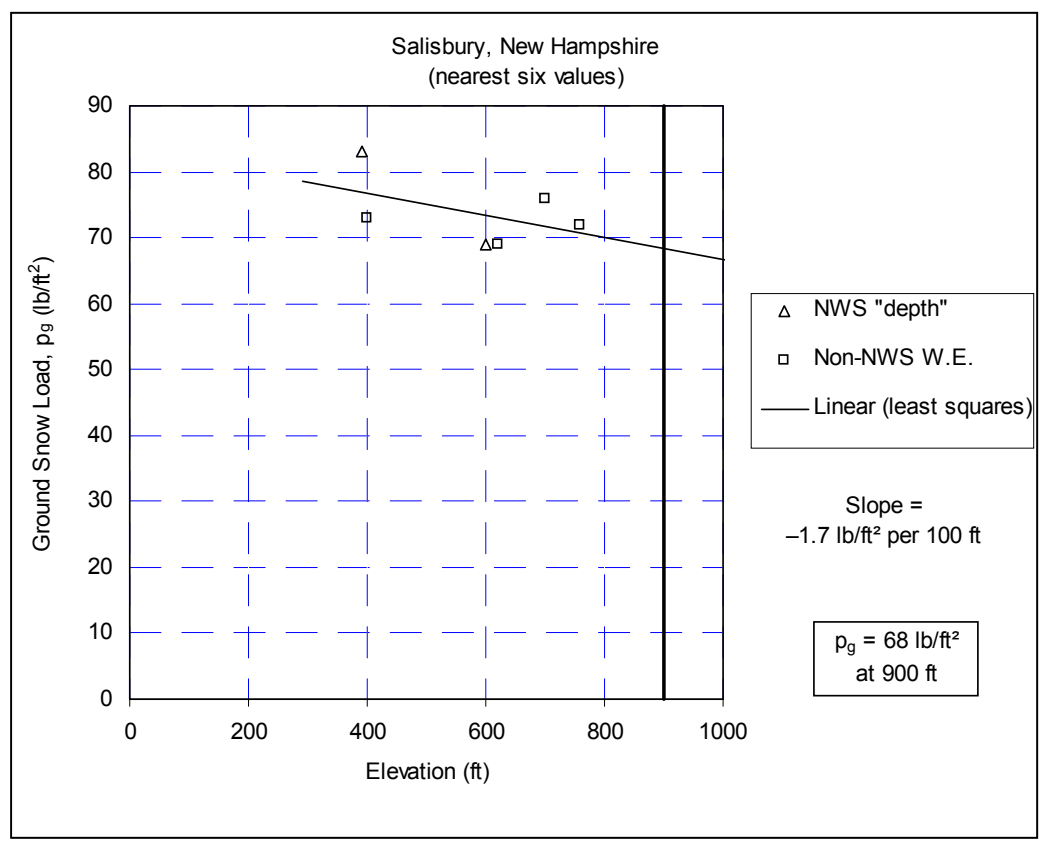

Salisbury, New Hampshire

(all values within 25 miles plus all NWS first-order values within 50 miles)

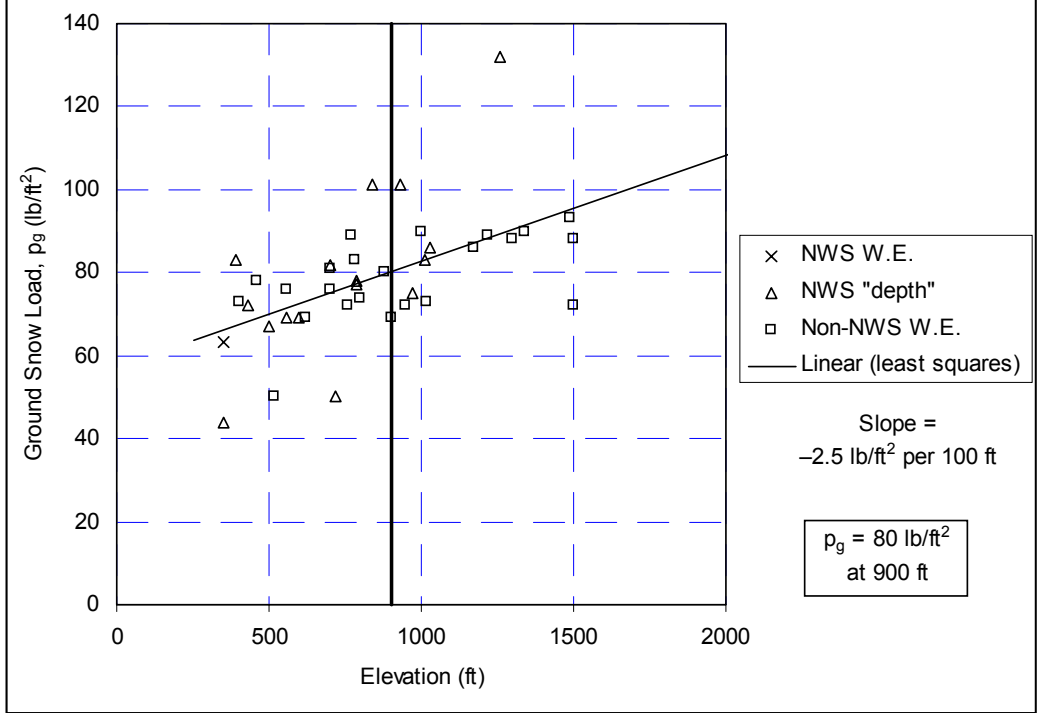

Figure 4. Case study plots for the town of Salisbury. Note that the scales on the two plots differ. NWS W.E. indicates a value based on snow load (i.e., water equivalent) measurements at a NWS first-order station. NWS "depth" indicates a load value based on snow depth measurements at a NWS first-order or co-op station. Non-NWS W.E. indicates a value based on snow load measurements at a non-NWS station. (To convert $\mathrm{lb} / \mathrm{ft}^{2}$ to $\mathrm{kN} / \mathrm{m}^{2}$, multiply by 0.048 ; for miles to $\mathrm{km}$, multiply by 1.61 ; for $\mathrm{lb} / \mathrm{ft}^{2}$ per $100 \mathrm{ft}$ to $\mathrm{kN} / \mathrm{m}^{2}$ per $100 \mathrm{~m}$, multiply by 0.157 .) 


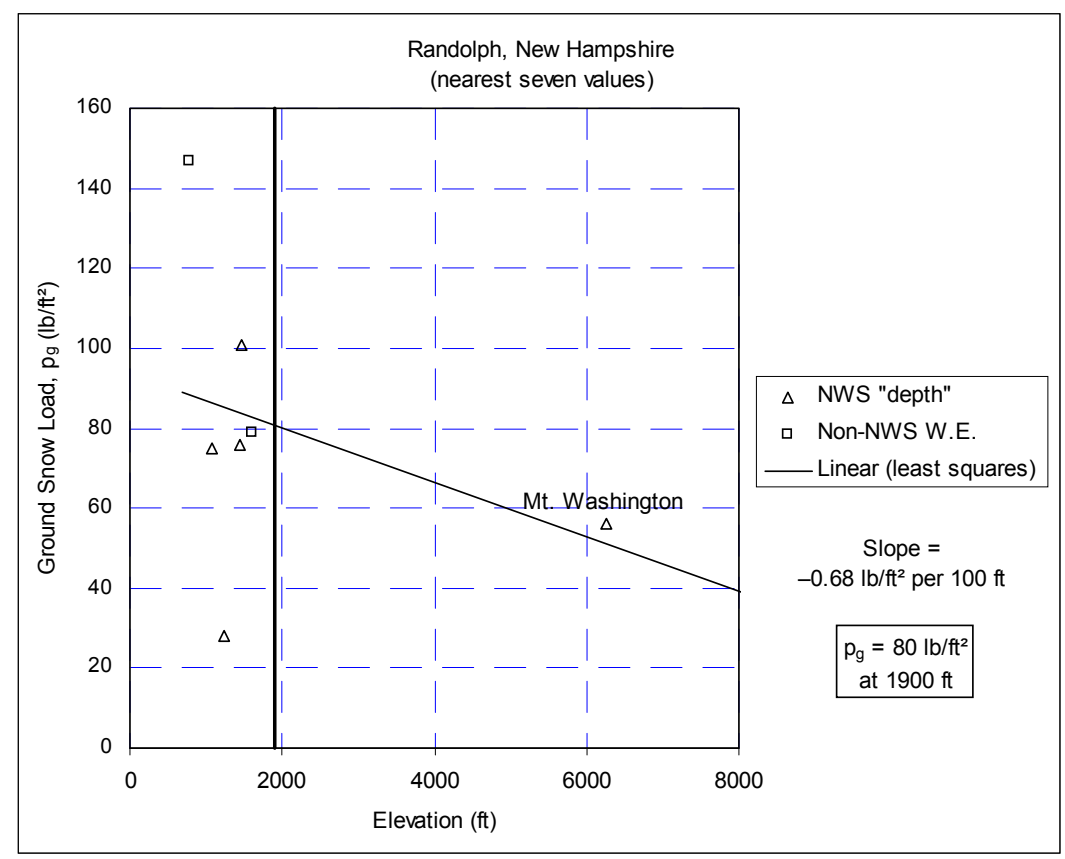

Figure 5. Nearest-values plot for Randolph, showing the adverse effect of the station near the windswept summit of Mt. Washington on the slope of the line of best fit. (To convert $\mathrm{lb} / \mathrm{ft}^{2}$ to $\mathrm{kN} / \mathrm{m}^{2}$, multiply by 0.048 ; for $\mathrm{ft}$ to $\mathrm{m}$, multiply by 0.305 ; for $\mathrm{lb} / \mathrm{ft}^{2}$ per $100 \mathrm{ft}$ to $\mathrm{kN} / \mathrm{m}^{2}$ per $100 \mathrm{~m}$, multiply by 0.157 .)

influences the nearest-values plot for Randolph. The line of best fit has a physically unrealistic negative slope, and the ground snow load where that line crosses the elevation of interest is too low to be accepted. The adverse influence of Mt. Washington's low value is very great for Randolph since the six remaining data points are all at much lower elevations and the elevation differences among them are relatively small. On the all-values plot, other stations counteract Mt. Washington's low value; the slope increases to $1.8 \mathrm{lb} / \mathrm{ft}^{2}$ per 100 $\mathrm{ft}\left(0.28 \mathrm{kN} / \mathrm{m}^{2}\right.$ per $\left.100 \mathrm{~m}\right)$, and the intercept at $1900 \mathrm{ft}(579 \mathrm{~m})$ increases to 111 $\mathrm{lb} / \mathrm{ft}^{2}\left(5.3 \mathrm{kN} / \mathrm{m}^{2}\right)$. When all this was considered, our answer for Randolph became $110 \mathrm{lb} / \mathrm{ft}^{2}\left(5.3 \mathrm{kN} / \mathrm{m}^{2}\right)$ at $1900 \mathrm{ft}(579 \mathrm{~m})$.

While Mt. Washington and a few other stations frustrated us, their implications were worth considering. Mt. Washington's redeeming value was to remind us that our elevation adjustment factor should not be applied above the treeline.

Each of the three CRREL researchers and the three SENH structural engineers involved was provided with (1) a copy of the "data and methodology" report mentioned previously (Tobiasson and Greatorex 1997), (2) several 
representative case studies done by CRREL previously, and (3) written guidance by Tobiasson and Greatorex for conducting case studies. That guidance is presented in Appendix B.

We began by working on 40 towns, about half of which were in the rugged northern portion of the state and the rest in the rolling hills of southwestern New Hampshire. We each conducted our analysis in our own way and forwarded our "preliminary" ground snow load answers and comments to two individuals at CRREL, who tallied them without divulging the author of each value and then sent the tally to each of us. We each privately re-assessed our answers in light of the answers and comments of the others and then sent in our "semi-final" answers, which were tallied in a similar fashion and returned to us.

We then developed a "team semi-final" answer, rounded to the nearest 5 $\mathrm{lb} / \mathrm{ft}^{2}\left(0.24 \mathrm{kN} / \mathrm{m}^{2}\right)$, for each town by throwing out the highest and lowest answer and averaging the remaining four answers. If that resulted in an answer exactly midway between possible rounded answers, we used any comments to go up or down. For example, if the four answers were 60,60, 65, and 65, and the only comment, provided with one of the 60 s, was, "perhaps 65 ," our answer would be 65. Had that comment been "perhaps 55," our answer would have been 60. If the "tie" could not be broken, we reconsidered the high and low answers and any comments associated with them. If a tie persisted, we then chose the higher value. On occasion, our discussions caused individuals to revise their semi-final answers during this process.

We met shortly thereafter to discuss our various methods of analysis and our answers and to arrive at a final answer for each of the 40 towns. At that meeting most of our time was spent resolving ties and discussing the difficulties mentioned above. As a result of our first meeting, we each made some changes to our method of analysis. We then repeated the process for the remaining 100 towns being studied in the portion of the state within the "CS" zone of the ASCE 7-98 snow load map. Our findings to that point are presented in Tobiasson et al. (2000). Thereafter, we ran the six-town test mentioned previously and decided to expand the scope of this project to include a case study for every town in the state. Before we conducted the remaining case studies, we made improvements to the case study forms, as will be discussed.

\section{$4 \quad$ VARIOUS WAYS OF ARRIVING AT ANSWERS}

The three individuals representing CRREL had done many case studies and were comfortable with the case study forms and the guidelines for analysis. They 
used the existing methodology, giving more weight to closer stations and stations with longer periods of record. They gave little weight to stations with less than about 15 years of record, and they gave little weight to stations where the ratio of the 50-year ground snow load (i.e., $p_{\mathrm{g}}$ on the case study tabulation) to the largest ground snow load ever measured there (i.e., the Record Max value on the case study tabulation, hereafter called $p_{\max }$ ) was greater than 1.6. (The $p_{\mathrm{g}} / p_{\max }$ ratio will be discussed further, later in this report.) They flagged such stations on the nearest-values plot and added a few stations somewhat farther away, but with longer periods of record, to replace them. Often more stations were added than were eliminated. Then they either "eyeballed" or calculated a new line of best fit in their quest for that case study's answer. When eyeballing a line of best fit, they gave it a slope of $2-2.5 \mathrm{lb} / \mathrm{ft}^{2}$ per $100 \mathrm{ft}\left(0.31-0.39 \mathrm{kN} / \mathrm{m}^{2}\right.$ per $\left.100 \mathrm{~m}\right)$, based on the written guidelines mentioned above and attached as Appendix B.

Two of them found it valuable to bound the filtered data by upper and lower lines at one of these slopes. Their answers were usually somewhat above the midpoint of the upper and lower bounds at the case study elevation. The third individual devoted additional attention to the geographical position of stations used in his analysis. He plotted the spatial relationship of stations surrounding the point of interest for some case studies.

The three practicing structural engineers from SENH had participated in the pilot study. Each had developed a slightly different way of doing case studies. They chose not to work on the case study plots, believing them to contain enough information of limited value to hide trends of interest. They only used the better stations in the data tabulation in their analyses, and they assumed an elevation adjustment factor of $2.0-2.5 \mathrm{lb} / \mathrm{ft}^{2}$ per $100 \mathrm{ft}\left(0.31-0.39 \mathrm{kN} / \mathrm{m}^{2}\right.$ per $\left.100 \mathrm{~m}\right)$.

One of them believed that the NWS co-op information, since it is based on measurements of the depth of snow on the ground, not measurements of the weight of that snow, is inferior to the non-NWS values, which are measurements of the weight. The other five individuals (two from SENH and three from CRREL) believed that the NWS and non-NWS data sets were of comparable value, each having its own strengths and weaknesses. For example, the few readings taken each winter at most of the non-NWS stations result in lower values since the annual maximum is likely to be missed, but it can also result in a bigger range of annual maximums. The net result can be to create either bigger or smaller 50-year ground snow loads than would result if readings were available daily, as they are for the NWS co-op stations.

The individual who focused on the non-NWS data included NWS information only when few non-NWS data were available. He sought to have 6 to 8 , and occasionally 10 , stations with 20 or more years of record in his analysis. 
He only used stations where the $p_{\mathrm{g}} / p_{\max }$ ratio was less than 1.5 . He re-plotted the $p_{\mathrm{g}}$ values selected vs. elevation and used a straight-line, least-squares fit to establish a preliminary answer. That answer was modified with consideration given to the slope of his trend line and the scatter of points. When several points at about the elevation of interest fell above the trend line, he increased his preliminary answer.

The other two SENH structural engineers considered both NWS and nonNWS data, but one of them gave more weight to the non-NWS information because it eliminated the step of having to relate snow depths to snow loads (see equation 1 in Tobiasson and Greatorex 1997). Both of these individuals developed selection criteria that eliminated from consideration a number of the stations on the case study form. The acceptance criteria of one individual were (1) at least 15 years of record; (2) less than 15, sometimes 20, miles (24, sometimes $32, \mathrm{~km}$ ) away; and (3) a $p_{\mathrm{g}} / p_{\max }$ ratio of no more than 1.75 for nonNWS stations and no more than 1.5 for NWS stations. The other individual's acceptance criteria were (1) at least 20 years of record; (2) less than 15 miles (24 $\mathrm{km}$ ) away; and (3) a $p_{\mathrm{g}} / p_{\max }$ ratio of no more than 1.5. Variations in the distance limit reflect terrain variability in the state and the number of stations available in the vicinity. Overall, their acceptance criteria were much the same as those used by the other four participants.

Both then adjusted each selected ground snow load to the case study elevation by using an elevation adjustment factor of $2.0-2.5 \mathrm{lb} / \mathrm{ft}^{2}$ per $100 \mathrm{ft}$ of elevation difference $\left(0.31-0.39 \mathrm{kN} / \mathrm{m}^{2}\right.$ per $\left.100 \mathrm{~m}\right)$. Both then determined the average value of the ground snow load at that elevation for all the stations selected. In the vicinity of Mt. Washington, where a station or two had a value quite different from this average, a second average was often calculated, eliminating the outliers. One individual developed separate averages for all data and for non-NWS data and gave more weight to the non-NWS average. He always plotted all the data he analyzed and frequently referred back to the case study plots before finalizing his answer.

A review of each individual's final answers indicates that no one's approach caused them to be consistently much lower or much higher than the group's final answer; the processes we each developed tended to generate similar answers. We expect that if any one of us had used our method of analysis alone, without receiving feedback from the others along the way, we may have arrived at significantly different answers for some towns. Thus, we conclude that there is great merit in involving several individuals in a way that they periodically receive anonymous feedback from each other. 
This process allowed the group to determine most answers before our meetings and precluded the need to discuss many of the case studies at those meetings. When we met, we concentrated on the few case studies on which we had remaining concerns or where there was a significant variation in answers. This left time for us to explore ways of improving the process, ways of simplifying our findings, and ways of incorporating them into the national standard (i.e., ASCE Standard 7) and into practice within New Hampshire. It also allowed us time to discuss our increasing understanding of the variation of ground snow loads in New Hampshire.

\section{$5 \quad p_{\mathrm{g}} / p_{\max }$ RATIO}

For 69 of the 302 stations shown in Figure 2, where a 50-year ground snow load $\left(p_{\mathrm{g}}\right)$ had been calculated, the $p_{\mathrm{g}} / p_{\max }$ ratio exceeded 1.5 . Often, the 50 -year ground snow load at such stations greatly exceeded other ground snow loads in the vicinity. For example, the upper data point in the all-values plot in Figure 4 has a high $p_{\mathrm{g}} / p_{\max }$ ratio of 1.7 . Responding to this complication proved to be the most controversial aspect of our analysis. To better understand what was happening, we examined probability plots of several of these stations and determined that, for them, the log-normal distribution used to generate the ground snow load values on the case study forms does not fit the actual trend in lower probabilities very well. Log-normal probability plots for Waterville Valley, Milford, and Milan are shown in Figure 6. The least-squares line of best fit (i.e., the log-normal answer) for Waterville Valley fits the data reasonably well at the $2 \%$ annual probability of being exceeded value (i.e., the 50 -year mean recurrence interval value), which is to be used for design. The $p_{\mathrm{g}} / p_{\max }$ ratio there is 1.11 . For Milford the log-normal answer greatly exceeds the data trend there. The $p_{\mathrm{g}} / p_{\max }$ ratio there is 1.76. For Milan the log-normal answer is well below the data trend and the $p_{\mathrm{g}} / p_{\max }$ ratio is 0.76 . Similar plots for other stations with high and low $p_{\mathrm{g}} / p_{\text {max }}$ ratios also indicated that the log-normal distribution did not fit those measured values that well. With this evidence we gave little weight in our analysis to stations with high or low $p_{\mathrm{g}} / p_{\max }$ ratios. 

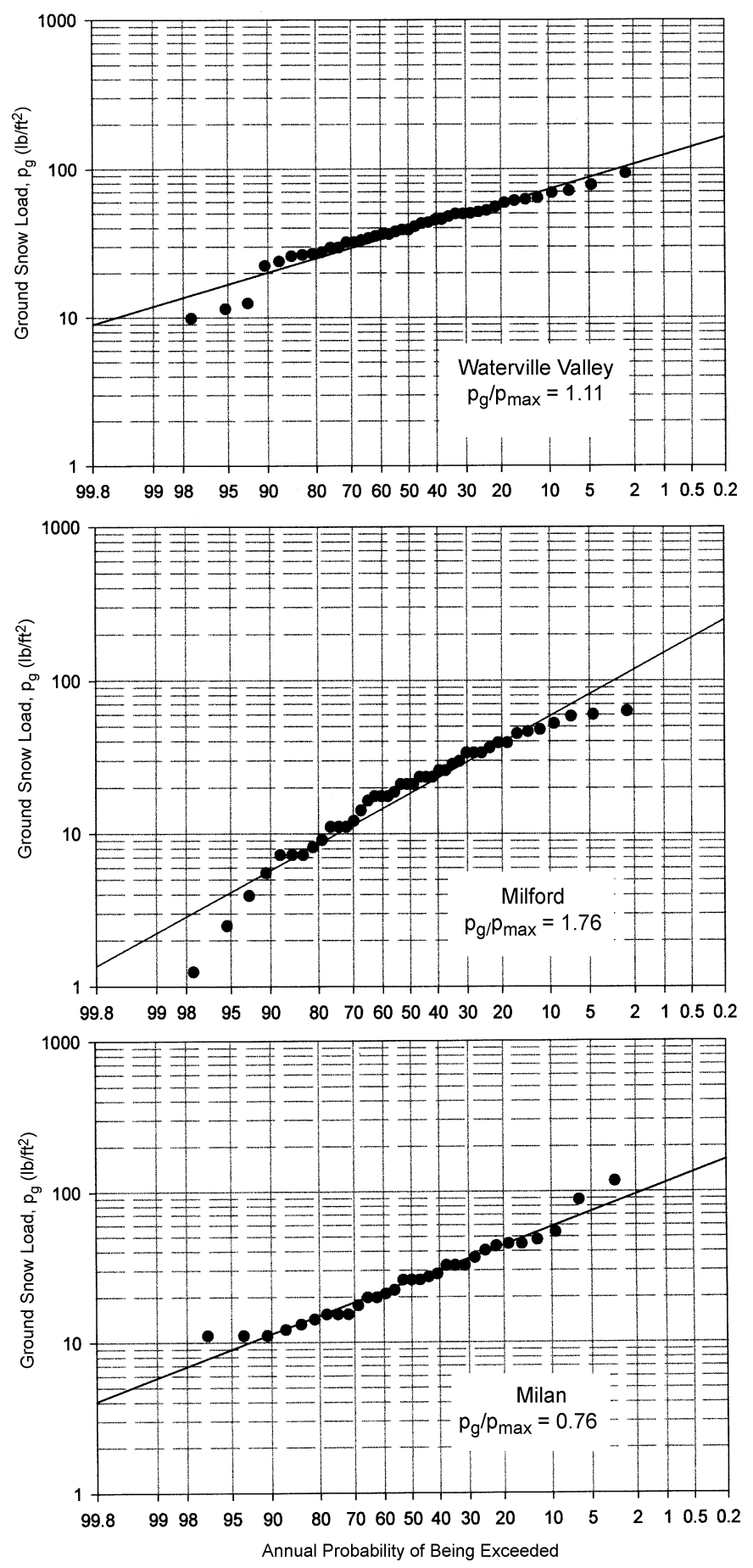

Figure 6. Log-normal probability plots for Waterville Valley, Milford, and Milan, which have $p_{\mathrm{g}} / p_{\max }$ ratios of $1.11,1.76$, and 0.76 , respectively. (To convert $\mathrm{lb} / \mathrm{ft}^{2}$ to $\mathrm{kN} / \mathrm{m}^{2}$, multiply by 0.048 .) 


\section{INTERCEPT COMPARISONS}

Once we had arrived at team answers for the first 140 case studies, we compared them to the intercept values on the nearest-values and all-values plots on the last page of those case study forms (e.g., Fig. 4). The nearest-values plot intercepts did not agree with our team answers well at all. Only 59 of them were within $5 \mathrm{lb} / \mathrm{ft}^{2}\left(0.2 \mathrm{kN} / \mathrm{m}^{2}\right)$ of our 140 team answers. For 50 stations the nearestvalues plot intercepts were from 10 to $38 \mathrm{lb} / \mathrm{ft}^{2}\left(0.5\right.$ to $\left.1.8 \mathrm{kN} / \mathrm{m}^{2}\right)$ away from our team answers. The all-values plot intercepts were within $5 \mathrm{lb} / \mathrm{ft}^{2}\left(0.2 \mathrm{kN} / \mathrm{m}^{2}\right)$ of our team answers for 116 of the 140 case studies (i.e., $83 \%$ of the time). However, for 8 stations the all-values intercepts were $10-20 \mathrm{lb} / \mathrm{ft}^{2}(0.5-1.0$ $\mathrm{kN} / \mathrm{m}^{2}$ ) away from our team answers. Thus, while the all-values intercepts provide good indications of our team answers most of the time, further study will occasionally result in significantly different, better answers.

\section{ELEVATION ADJUSTMENT FACTOR}

The elevation adjustment factor was also examined on the nearest-values and all-values plots of the first 140 case studies. It is the slope of the line of best fit on those plots (e.g., see Fig. 4). On the nearest-values plot that factor varied widely between $13.5 \mathrm{lb} / \mathrm{ft}^{2}$ per $100 \mathrm{ft}\left(2.12 \mathrm{kN} / \mathrm{m}^{2}\right.$ per $\left.100 \mathrm{~m}\right)$ and $-9.0 \mathrm{lb} / \mathrm{ft}^{2}$ per $100 \mathrm{ft}$ $\left(-1.41 \mathrm{kN} / \mathrm{m}^{2}\right.$ per $\left.100 \mathrm{~m}\right)$. The average value of this widely divergent set of numbers was $1.8 \mathrm{lb} / \mathrm{ft}^{2}$ per $100 \mathrm{ft}\left(0.28 \mathrm{kN} / \mathrm{m}^{2}\right.$ per $\left.100 \mathrm{~m}\right)$. We place little value on this average, as it is significantly influenced by some slopes that are physically unrealistic. Stations such as Mt. Washington create these inappropriate slopes. On the all-values plot the slopes make somewhat better physical sense, but Mt.

Washington and a few other stations still create problems. These slopes vary from $5.3 \mathrm{lb} / \mathrm{ft}^{2}$ per $100 \mathrm{ft}\left(0.83 \mathrm{kN} / \mathrm{m}^{2}\right.$ per $\left.100 \mathrm{~m}\right)$ to $-3.0 \mathrm{lb} / \mathrm{ft}^{2}$ per $100 \mathrm{ft}\left(-0.47 \mathrm{kN} / \mathrm{m}^{2}\right.$ per $100 \mathrm{~m})$ and average $2.4 \mathrm{lb} / \mathrm{ft}^{2}$ per $100 \mathrm{ft}\left(0.38 \mathrm{kN} / \mathrm{m}^{2}\right.$ per $\left.100 \mathrm{~m}\right)$.

We further examined the elevation adjustment factor by studying each station in our database. We excluded stations with less than 15 years of record, others with an elevation above $2500 \mathrm{ft}(762 \mathrm{~m})$, and others with $p_{\mathrm{g}} / p_{\max }$ ratios less than 0.9 or greater than 1.7. For the remaining stations the line of best fit of their elevation to their 50-year ground snow load, $p_{\mathrm{g}}$, produced a slope of $2.1 \mathrm{lb} / \mathrm{ft}^{2}$ per $100 \mathrm{ft}\left(0.33 \mathrm{kN} / \mathrm{m}^{2}\right.$ per $\left.100 \mathrm{~m}\right)$, as shown in Figure 7. While we expect that the elevation adjustment factor varies from place to place in New Hampshire, we do not have enough data to support such differences. Thus, we have used an elevation adjustment factor of $2.1 \mathrm{lb} / \mathrm{ft}^{2}$ per $100 \mathrm{ft}\left(0.33 \mathrm{kN} / \mathrm{m}^{2}\right.$ per $\left.100 \mathrm{~m}\right)$ for all New Hampshire towns. 


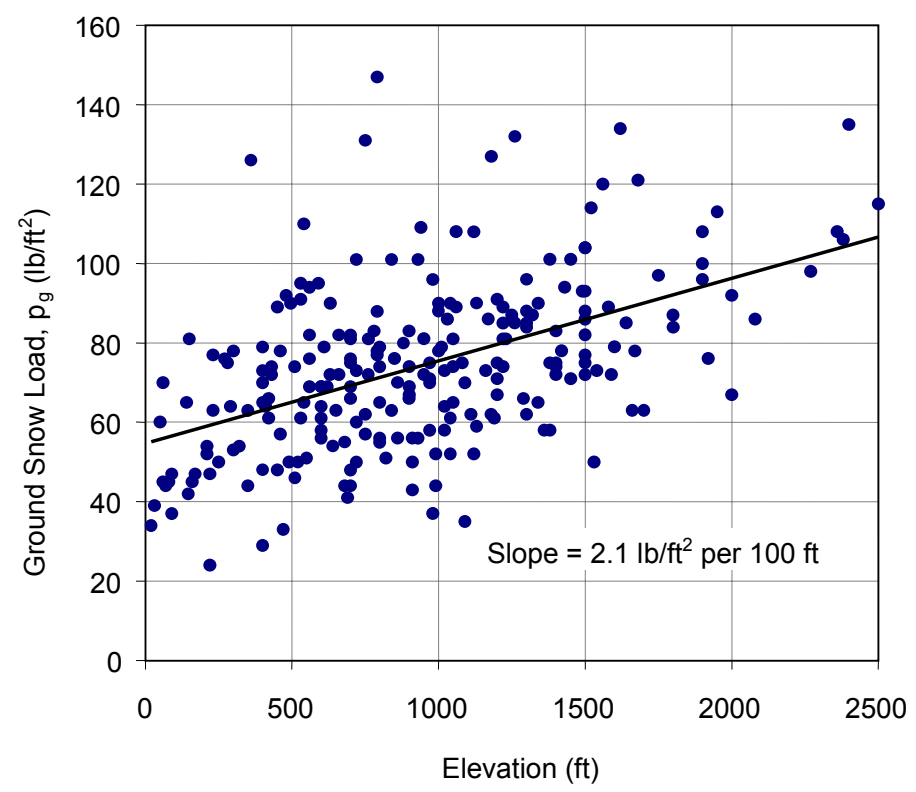

Figure 7. Elevation adjustment factor for the 236 highest-quality stations used in our analyses: 2.1 $\mathrm{lb} / \mathrm{ft}^{2}$ per $100 \mathrm{ft}\left(0.33 \mathrm{kN} / \mathrm{m}^{2}\right.$ per $\left.100 \mathrm{~m}\right)$. (To convert $\mathrm{lb} / \mathrm{ft}^{2}$ to $\mathrm{kN} / \mathrm{m}^{2}$, multiply by 0.048 ; for $\mathrm{ft}$ to $\mathrm{m}$, multiply by 0.0305 .)

We have not fully investigated the upper limit above which our elevation adjustment factor does not apply. At this time it seems safe to use it up to an elevation of $2500 \mathrm{ft}$ (762 m) in New Hampshire, which is well below the treeline. At higher elevations up to the treeline, which is at about $4500 \mathrm{ft}(1370 \mathrm{~m})$ in New Hampshire, a larger elevation adjustment factor may be needed. Above the treeline the use of an elevation adjustment factor may not be appropriate. Thus, at all places above $2500 \mathrm{ft}$ (762 m) in New Hampshire, case studies are still needed to determine ground snow loads. Since few structures are built above $2500 \mathrm{ft}$ (762 m) in New Hampshire, our upper limit affects very little construction.

\section{ONE LOAD AND ONE ELEVATION CORRECTION FACTOR FOR ALL OF NEW HAMPSHIRE?}

After we had completed the first 140 case studies, in an attempt to make our final product as user friendly as possible, we investigated the possibility of simplifying all this to a single "New Hampshire ground snow load" with a single "New Hampshire elevation adjustment factor." We used an elevation adjustment factor to bring our 140 case study answers to an elevation of $1000 \mathrm{ft}$ (305 m) and 
then displayed those values on a map of the state. Had they all been about the same, the proposed simplification would have been possible. However, they ranged from lows of $60-70 \mathrm{lb} / \mathrm{ft}^{2}\left(2.9-3.4 \mathrm{kN} / \mathrm{m}^{2}\right)$ in the northern portion of the state to $90-100 \mathrm{lb} / \mathrm{ft}^{2}\left(4.3-4.8 \mathrm{kN} / \mathrm{m}^{2}\right)$ progressing south into the heart of the White Mountains, then back down to $75-85 \mathrm{lb} / \mathrm{ft}^{2}\left(3.6-4.1 \mathrm{kN} / \mathrm{m}^{2}\right)$ farther south in the central portion of the "CS" area shown in Figure 1, then to $70-80 \mathrm{lb} / \mathrm{ft}^{2}$ $\left(3.4-3.8 \mathrm{kN} / \mathrm{m}^{2}\right)$ in the southwestern portion of the state (i.e., the bottom of the "CS" zone in Figure 1). We concluded that this amount of variability would preclude the simplification that we hoped might be possible.

\section{MODIFICATION OF CASE STUDY TABULATIONS AND PLOTS}

After achieving our initial objective of establishing ground snow loads for 140 towns in the "CS" area of the snow load map in ASCE Standard 7 and doing, as a test, case studies for six towns not in the "CS" zone, we decided to expand our coverage to include the rest of the state. However, before proceeding, we agreed to improve the case study forms and plots. Values of the $p_{\mathrm{g}} / p_{\max }$ ratio were added to the tabulation. The Salisbury tabulation in Figure 3 does, in fact, contain the $p_{\mathrm{g}} / p_{\max }$ ratios along the right margin to illustrate that improvement. We excluded from the plots, stations with any of the following:

- Less than 15 years of record;

- $\quad \mathrm{A} p_{\mathrm{g}} / p_{\max }$ ratio in excess of 1.7 ;

- $\mathrm{A} p_{\mathrm{g}} / p_{\max }$ ratio less than 0.9 ; or

- An elevation above $2500 \mathrm{ft}$ (762 m).

Thus, on these newer plots the captions (e.g., "nearest six values" and "all values") refer to stations that were not excluded. Any station not plotted was shown in subdued print on the tabulation. These improvements noticeably reduced the time it took each of us to do the 113 remaining case studies. The plots in Figure 4 are not the improved versions.

\section{TIME DEVOTED TO THE ANALYSIS}

Obtaining the latitudes, longitudes, and elevations in Appendix A from the USGS "quad sheets" was time consuming. Each town took about 12.5 minutes when two of us worked together. Thus, 0.42 man-hours were spent on this per town, for a total of 108 man-hours. 
Once the latitude, longitude, and elevation for each case study were determined, a case study tabulation and plots were computer-generated for each town. When only one or two of these are done at a sitting, each case study takes about 30 minutes. About half that time is spent developing maps of the area and verifying that the elevation provided fits. However, with over 100 case study forms to do at once, and with no mapping necessary, the 259 forms for this study were produced by one individual at a rate of about one every 5.6 minutes, for a total of 24 man-hours.

We analyzed the case studies in three phases. Phase 1 involved the first 40. Some of those case studies took twice as long as others, and we all worked at different rates. During the latter portions of Phase 1 most of our time and attention were directed to the few towns where the group had a divergence of opinion. We met for most of a day to finalize our answers on these 40 towns. On Phase 1 we each spent an average of 32.5 minutes per town. Since there were six of us doing each case study, in total we spent 3.25 man-hours per town. This includes the time we spent meeting to discuss our answers and reach a consensus.

An additional 106 case studies were conducted in Phase 2. The average time each of us spent on each Phase 2 town was about 24.2 minutes, for a total of 2.42 man-hours per town. Our pace for Phase 2 was somewhat faster than for Phase 1, which was to be expected.

The final 113 case studies were done in Phase 3. Our average time to do each case study dropped to only 19.1 minutes. Thus, 1.91 man-hours were spent on each Phase 3 town. A portion of the reduction in time for Phase 3 can be attributed to our improving abilities, while another portion was due to the fact that these case studies were in flatter areas of the state, outside the "CS" zone, where answers were easier to obtain from the database. The changes made to the case study forms prior to doing the final 113 case studies significantly reduced the time we spent filtering out data that did not meet our selection criteria.

For the entire project involving 259 towns, our average analysis time per case study was 23.3 minutes, so we devoted an average of 2.33 man-hours to the analysis of each town. The total time spent on the analysis of case study forms was 603 man-hours.

When the times to establish the latitude, longitude, and elevation of each town, produce the case study forms, manage this process, and have a third party compile our various answers in such a way to provide anonymous feedback are also considered, the total time for each case study was 3.15 man-hours. In total, we devoted 815 man-hours to this analysis and averaged 31.5 minutes per case study. 
When the time to develop this co-operative agreement, conduct various studies as questions arose, write and present a conference paper, produce this final report, prepare a letter to each town in New Hampshire, have our findings incorporated into the Commentary of ASCE 7-02, and make several presentations on this work at gatherings of engineers is included, the total time increases to about 2000 man-hours.

About $60 \%$ of the work reported here was done on a volunteer basis. All of us had difficulties, at one time or another, finding time for this big volunteer project among our other activities.

\section{FINDINGS}

Our answers for New Hampshire's 259 towns are presented in Table 1. The location of each town is shown in Figure 8. The numbers on the map are those in Table 1 just to the left of the names of the towns. The ground snow load given in Table 1 only applies at the elevation listed beside it. To determine the ground snow load at elevations other than those listed in Table 1 (i.e., at elevations other than those where the case studies were conducted), the values in Table 1 should be increased or decreased by an elevation adjustment factor of $2.1 \mathrm{lb} / \mathrm{ft}^{2}$ per 100 $\mathrm{ft}\left(0.33 \mathrm{kN} / \mathrm{m}^{2}\right.$ per $\left.100 \mathrm{~m}\right)$. For example, in Hanover, where the Table 1 value is $75 \mathrm{lb} / \mathrm{ft}^{2}$ at $1300 \mathrm{ft}\left(3.6 \mathrm{kN} / \mathrm{m}^{2}\right.$ at $\left.396 \mathrm{~m}\right)$, at an elevation of $900 \mathrm{ft}(274 \mathrm{~m})$ the answer would be

$$
75+(2.1 / 100)(900-1300)=75-8=67 \mathrm{lb} / \mathrm{ft}^{2}
$$

or

$3.6+(0.33 / 100)(274-396)=3.6-0.4=3.2 \mathrm{kN} / \mathrm{m}^{2}$.

In Hanover at an elevation of $1600 \mathrm{ft}(488 \mathrm{~m})$ the answer would be

$75+6=81 \mathrm{lb} / \mathrm{ft}^{2}$

or

$3.6+0.3=3.9 \mathrm{kN} / \mathrm{m}^{2}$.

Since it is common to round ground snow loads to the nearest $5 \mathrm{lb} / \mathrm{ft}^{2}(0.24$ $\left.\mathrm{kN} / \mathrm{m}^{2}\right), 67 \mathrm{lb} / \mathrm{ft}^{2}\left(3.2 \mathrm{kN} / \mathrm{m}^{2}\right)$ would round to $65 \mathrm{lb} / \mathrm{ft}^{2}\left(3.1 \mathrm{kN} / \mathrm{m}^{2}\right)$ and $81 \mathrm{lb} / \mathrm{ft}^{2}$ $\left(3.9 \mathrm{kN} / \mathrm{m}^{2}\right)$ would round to $80 \mathrm{lb} / \mathrm{ft}^{2}\left(3.8 \mathrm{kN} / \mathrm{m}^{2}\right)$. 


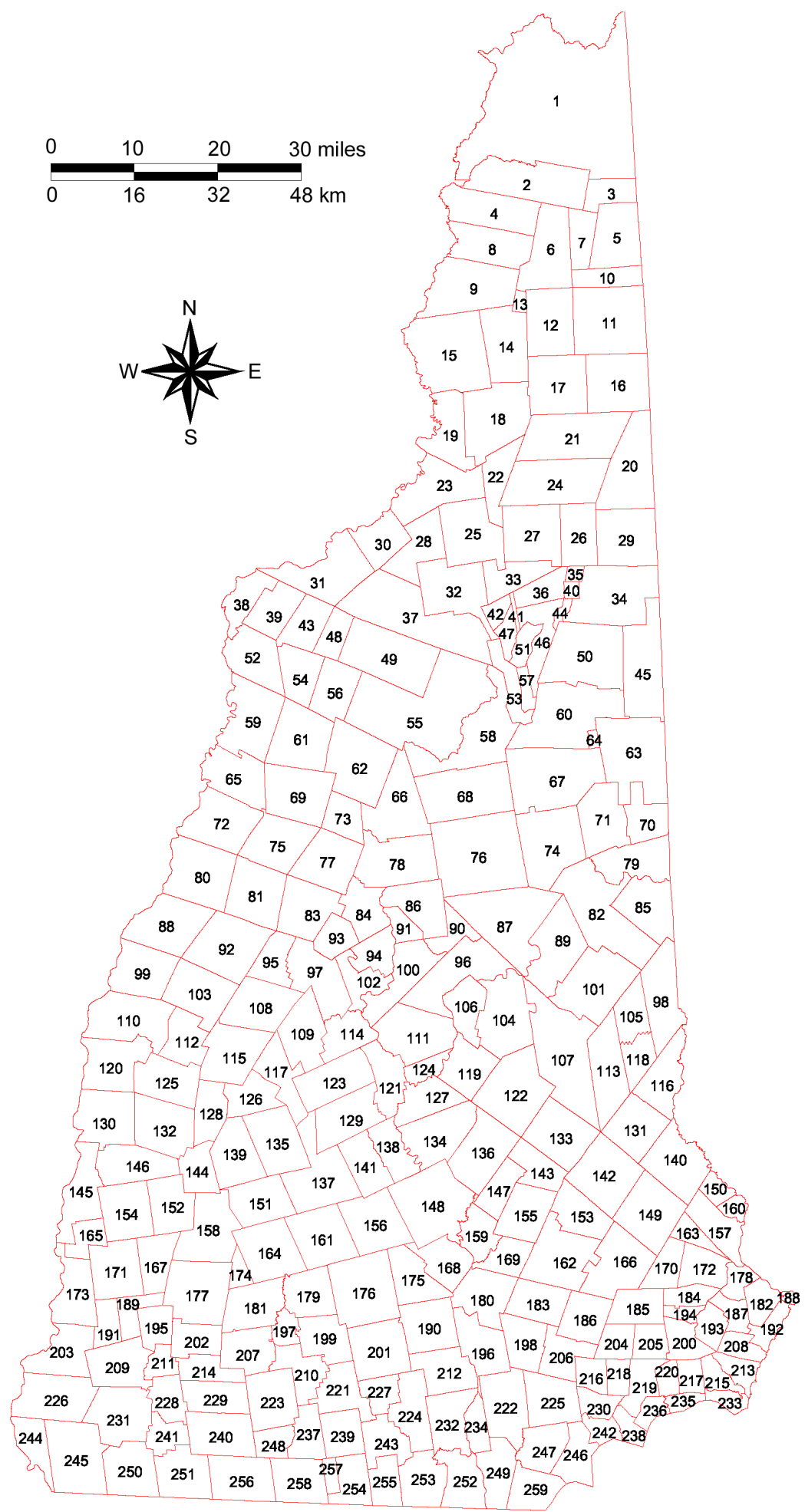

Figure 8. Location of each New Hampshire town presented in Table 1. 
Table 1. Ground snow load $\left(p_{g}\right)$ at a specific elevation for all New Hampshire towns.

\begin{tabular}{|c|c|c|c|c|c|c|c|c|c|}
\hline $\begin{array}{c}\text { Map } \\
\text { no. }\end{array}$ & Town & $\begin{array}{c}p_{\mathrm{g}}{ }^{*} \\
\left(\mathrm{Ib} / \mathrm{ft}^{2}\right)^{\dagger}\end{array}$ & & $\begin{array}{c}\text { Elevation } \\
(\mathrm{ft})^{\star *}\end{array}$ & $\begin{array}{l}\text { Map } \\
\text { no. }\end{array}$ & Town & $\begin{array}{c}p_{\mathrm{g}}{ }^{*} \\
\left(\mathrm{Ib} / \mathrm{ft}^{2}\right)^{\dagger}\end{array}$ & & $\begin{array}{c}\text { Elevation } \\
(\mathrm{ft})^{* *}\end{array}$ \\
\hline 154 & Acworth & 90 & $@$ & 1500 & 102 & Bristol & 80 & $@$ & 1000 \\
\hline 67 & Albany & 95 & $@$ & 1300 & 105 & Brookfield & 90 & $@$ & 800 \\
\hline 97 & Alexandria & 85 & $@$ & 1100 & 255 & Brookline & 60 & $@$ & 500 \\
\hline 169 & Allenstown & 70 & $@$ & 700 & 16 & Cambridge & 90 & $@$ & 1300 \\
\hline 171 & Alstead & 80 & $@$ & 1300 & 78 & Campton & 85 & $@$ & 1300 \\
\hline 107 & Alton & 90 & $@$ & 900 & 92 & Canaan & 80 & $@$ & 1200 \\
\hline 224 & Amherst & 70 & $@$ & 600 & 183 & Candia & 75 & $@$ & 700 \\
\hline 123 & Andover & 80 & $@$ & 900 & 134 & Canterbury & 80 & $@$ & 900 \\
\hline 181 & Antrim & 80 & $@$ & 1000 & 32 & Carroll & 95 & $@$ & 1700 \\
\hline 91 & Ashland & 75 & $@$ & 800 & 90 & Center Harbor & 80 & $@$ & 900 \\
\hline 242 & Atkinson & 55 & $@$ & 400 & 41 & Chandlers Purchase & 120 & $@$ & 2500 \\
\hline \multirow[t]{2}{*}{3} & \multirow{2}{*}{$\begin{array}{l}\text { Atkinson \& Gilmanton } \\
\text { Academy Grant }\end{array}$} & \multirow[t]{2}{*}{85} & \multirow[t]{2}{*}{$@$} & \multirow[t]{2}{*}{1600} & 145 & Charlestown & 80 & $@$ & 1100 \\
\hline & & & & & 45 & Chatham & 90 & $@$ & 500 \\
\hline 198 & Auburn & 65 & $@$ & 500 & 206 & Chester & 65 & $@$ & 500 \\
\hline 133 & Barnstead & 85 & $@$ & 900 & 226 & Chesterfield & 70 & $@$ & 1000 \\
\hline 149 & Barrington & 70 & $@$ & 500 & 147 & Chichester & 75 & $@$ & 700 \\
\hline 60 & Bartlett & 100 & $@$ & 1200 & 130 & Claremont & 85 & $@$ & 1100 \\
\hline 52 & Bath & 65 & $@$ & 1000 & 2 & Clarksville & 90 & $@$ & 2000 \\
\hline 47 & Beans Grant & 105 & $@$ & 1800 & 8 & Colebrook & 80 & $@$ & 1600 \\
\hline 34 & Beans Purchase & 120 & $@$ & 2000 & 9 & Columbia & 80 & $@$ & 1600 \\
\hline 212 & Bedford & 70 & $@$ & 700 & 148 & Concord & 70 & $@$ & 600 \\
\hline 119 & Belmont & 80 & $@$ & 900 & 63 & Conway & 95 & $@$ & 900 \\
\hline 197 & Bennington & 80 & $@$ & 1000 & 120 & Cornish & 85 & $@$ & 1100 \\
\hline 61 & Benton & 90 & $@$ & 1600 & 42 & Crawfords Purchase & 110 & $@$ & 1800 \\
\hline 24 & Berlin & 100 & $@$ & 1600 & 125 & Croydon & 90 & $@$ & 1200 \\
\hline 37 & Bethlehem & 105 & $@$ & 1800 & 51 & Cutts Grant & 110 & $@$ & 1700 \\
\hline 138 & Boscawen & 75 & $@$ & 700 & 30 & Dalton & 80 & $@$ & 1300 \\
\hline 168 & Bow & 75 & $@$ & 800 & 109 & Danbury & 85 & $@$ & 1000 \\
\hline 151 & Bradford & 85 & $@$ & 1200 & 218 & Danville & 55 & $@$ & 300 \\
\hline 205 & Brentwood & 50 & @ & 250 & 162 & Deerfield & 70 & $@$ & 700 \\
\hline 94 & Bridgewater & 80 & $@$ & 1000 & 179 & Deering & 85 & $@$ & 1200 \\
\hline
\end{tabular}

* These loads only apply at the elevations listed. For lower elevations reduce the load by $2.1 \mathrm{lb} / \mathrm{ft}^{2}$ for every $100 \mathrm{ft}$ of elevation difference. For higher elevations up to $2500 \mathrm{ft}$, increase the load by $2.1 \mathrm{lb} / \mathrm{ft}^{2}$ for every $100 \mathrm{ft}$ of elevation difference. Examples are presented in the text. Do not use this information above $2500 \mathrm{ft}$ : Conduct a site-specific snow load case study.

$\dagger \quad$ To convert $\mathrm{lb} / \mathrm{ft}^{2}$ to $\mathrm{kN} / \mathrm{m}^{2}$, multiply by 0.048 .

** To convert feet to meters, multiply by 0.305 . 
Table 1 (cont.). Ground snow load $\left(p_{\mathrm{g}}\right)$ at a specific elevation for all New Hampshire towns.

\begin{tabular}{|c|c|c|c|c|c|c|c|c|c|}
\hline $\begin{array}{c}\text { Map } \\
\text { no. }\end{array}$ & Town & $\begin{array}{c}p_{\mathrm{g}}{ }^{*} \\
\left(\mathrm{lb} / \mathrm{ft}^{2}\right)^{\dagger}\end{array}$ & & $\begin{array}{c}\text { Elevation } \\
(\mathrm{ft})^{\star \star}\end{array}$ & $\begin{array}{c}\text { Map } \\
\text { no. }\end{array}$ & Town & $\begin{array}{c}p_{\mathrm{g}}{ }^{*} \\
\left(\mathrm{Ib} / \mathrm{ft}^{2}\right)^{\dagger}\end{array}$ & & $\begin{array}{c}\text { Elevation } \\
(\mathrm{ft})^{\star \star}\end{array}$ \\
\hline 225 & Derry & 65 & $@$ & 600 & 26 & Gorham & 100 & $@$ & 1400 \\
\hline 7 & Dixs Grant & 90 & @ & 1700 & 144 & Goshen & 90 & @ & 1400 \\
\hline 6 & Dixville & 90 & $@$ & 1900 & 108 & Grafton & 90 & @ & 1400 \\
\hline 81 & Dorchester & 80 & $@$ & 1400 & 112 & Grantham & 90 & @ & 1400 \\
\hline 157 & Dover & 60 & $@$ & 200 & 210 & Greenfield & 80 & @ & 1100 \\
\hline 229 & Dublin & 90 & $@$ & 1600 & 187 & Greenland & 50 & @ & 100 \\
\hline 17 & Dummer & 90 & @ & 1400 & 40 & Greens Grant & 105 & @ & 1700 \\
\hline 175 & Dunbarton & 75 & $@$ & 800 & 257 & Greenville & 75 & @ & 1000 \\
\hline 172 & Durham & 55 & @ & 150 & 83 & Groton & 80 & @ & 1200 \\
\hline 220 & East Kingston & 50 & $@$ & 200 & 57 & Hadleys Purchase & 100 & @ & 1500 \\
\hline 56 & Easton & 85 & @ & 1400 & 64 & Hales Location & 90 & @ & 800 \\
\hline 70 & Eaton & 95 & @ & 1000 & 230 & Hampstead & 55 & @ & 300 \\
\hline 85 & Effingham & 85 & $@$ & 600 & 213 & Hampton & 50 & @ & 150 \\
\hline 73 & Ellsworth & 90 & @ & 1400 & 215 & Hampton Falls & 50 & $@$ & 150 \\
\hline 103 & Enfield & 85 & @ & 1300 & 207 & Hancock & 85 & @ & 1300 \\
\hline 185 & Epping & 55 & $@$ & 300 & 88 & Hanover & 75 & $@$ & 1300 \\
\hline 155 & Epsom & 75 & $@$ & 800 & 214 & Harrisville & 90 & @ & 1500 \\
\hline 11 & Errol & 90 & $@$ & 1600 & 53 & Harts Location & 100 & @ & 1300 \\
\hline 13 & Ervings Location & 100 & $@$ & 2100 & 59 & Haverhill & 75 & $@$ & 1200 \\
\hline 200 & Exeter & 50 & @ & 200 & 93 & Hebron & 80 & @ & 900 \\
\hline 131 & Farmington & 85 & $@$ & 800 & 161 & Henniker & 80 & $@$ & 1000 \\
\hline 251 & Fitzwilliam & 75 & $@$ & 1300 & 114 & Hill & 85 & $@$ & 1100 \\
\hline 199 & Francestown & 80 & @ & 1100 & 164 & Hillsborough & 80 & $@$ & 1000 \\
\hline 49 & Franconia & 95 & $@$ & 1700 & 244 & Hinsdale & 60 & @ & 700 \\
\hline 121 & Franklin & 75 & @ & 700 & 86 & Holderness & 80 & @ & 1000 \\
\hline 79 & Freedom & 90 & $@$ & 1000 & 253 & Hollis & 60 & @ & 500 \\
\hline 204 & Fremont & 50 & $@$ & 250 & 180 & Hooksett & 70 & @ & 600 \\
\hline 104 & Gilford & 90 & @ & 1200 & 156 & Hopkinton & 80 & @ & 800 \\
\hline 122 & Gilmanton & 90 & $@$ & 1100 & 249 & Hudson & 60 & @ & 400 \\
\hline 189 & Gilsum & 80 & @ & 1200 & 50 & Jackson & 115 & @ & 1800 \\
\hline 190 & Goffstown & 75 & @ & 800 & 240 & Jaffrey & 80 & @ & 1300 \\
\hline
\end{tabular}

* These loads only apply at the elevations listed. For lower elevations reduce the load by $2.1 \mathrm{lb} / \mathrm{ft}^{2}$ for every $100 \mathrm{ft}$ of elevation difference. For higher elevations up to $2500 \mathrm{ft}$, increase the load by $2.1 \mathrm{lb} / \mathrm{ft}^{2}$ for every $100 \mathrm{ft}$ of elevation difference. Examples are presented in the text. Do not use this information above $2500 \mathrm{ft}$ : Conduct a site-specific snow load case study.

$\dagger \quad$ To convert $\mathrm{lb} / \mathrm{ft}^{2}$ to $\mathrm{kN} / \mathrm{m}^{2}$, multiply by 0.048 .

** To convert feet to meters, multiply by 0.305 . 
Table 1 (cont.). Ground snow load $\left(p_{\mathrm{g}}\right)$ at a specific elevation for all New Hampshire towns.

\begin{tabular}{|c|c|c|c|c|c|c|c|c|c|}
\hline $\begin{array}{l}\text { Map } \\
\text { no. }\end{array}$ & Town & $\begin{array}{c}p_{\mathrm{g}}{ }^{*} \\
\left(\mathrm{lb} / \mathrm{ft}^{2}\right)^{\dagger}\end{array}$ & & $\begin{array}{c}\text { Elevation } \\
(\mathrm{ft})^{\star *}\end{array}$ & $\begin{array}{c}\text { Map } \\
\text { no. }\end{array}$ & Town & $\begin{array}{c}p_{g}{ }^{*} \\
\left(\mathrm{lb} / \mathrm{ft}^{2}\right)^{\dagger}\end{array}$ & & $\begin{array}{c}\text { Elevation } \\
(\mathrm{ft})^{\star *}\end{array}$ \\
\hline 25 & Jefferson & 100 & $@$ & 1700 & 232 & Merrimack & 60 & $@$ & 400 \\
\hline 209 & Keene & 70 & $@$ & 900 & 118 & Middleton & 90 & $@$ & 800 \\
\hline 217 & Kensington & 50 & $@$ & 200 & 21 & Milan & 95 & $@$ & 1500 \\
\hline 22 & Kilkenny & 95 & $@$ & 1700 & 243 & Milford & 70 & @ & 600 \\
\hline 219 & Kingston & 50 & $@$ & 200 & 12 & Millsfield & 90 & @ & 1700 \\
\hline 106 & Laconia & 80 & $@$ & 900 & 116 & Milton & 90 & @ & 800 \\
\hline 23 & Lancaster & 75 & $@$ & 1300 & 38 & Monroe & 65 & $@$ & 1000 \\
\hline 54 & Landaff & 80 & $@$ & 1300 & 227 & Mont Vernon & 75 & $@$ & 900 \\
\hline 165 & Langdon & 80 & $@$ & 1000 & 87 & Moultonborough & 80 & $@$ & 900 \\
\hline 99 & Lebanon & 80 & $@$ & 1200 & 252 & Nashua & 60 & $@$ & 400 \\
\hline 170 & Lee & 55 & $@$ & 200 & 202 & Nelson & 90 & $@$ & 1500 \\
\hline 152 & Lempster & 95 & $@$ & 1600 & 201 & New Boston & 80 & $@$ & 800 \\
\hline 55 & Lincoln & 95 & $@$ & 1400 & 188 & New Castle & 50 & $@$ & 50 \\
\hline 43 & Lisbon & 75 & $@$ & 1100 & 113 & New Durham & 90 & $@$ & 900 \\
\hline 234 & Litchfield & 60 & $@$ & 250 & 100 & New Hampton & 80 & $@$ & 1000 \\
\hline 31 & Littleton & 75 & @ & 1200 & 258 & New Ipswich & 80 & $@$ & 1300 \\
\hline 58 & Livermore & 100 & @ & 1500 & 126 & New London & 95 & $@$ & 1400 \\
\hline 222 & Londonderry & 65 & @ & 500 & 139 & Newbury & 90 & $@$ & 1300 \\
\hline 136 & Loudon & 80 & $@$ & 900 & 194 & Newfields & 50 & @ & 150 \\
\hline \multirow[t]{2}{*}{33} & \multirow{2}{*}{$\begin{array}{l}\text { Low \& Burbanks } \\
\text { Grant }\end{array}$} & \multirow[t]{2}{*}{105} & \multirow[t]{2}{*}{$@$} & \multirow[t]{2}{*}{1800} & 178 & Newington & 50 & @ & 100 \\
\hline & & & & & 184 & Newmarket & 50 & @ & 200 \\
\hline 39 & Lyman & 75 & $@$ & 1200 & 132 & Newport & 85 & @ & 1200 \\
\hline 80 & Lyme & 70 & $@$ & 1100 & 236 & Newton & 50 & @ & 250 \\
\hline 221 & Lyndeborough & 80 & $@$ & 1000 & 208 & North Hampton & 50 & @ & 100 \\
\hline 163 & Madbury & 60 & $@$ & 200 & 127 & Northfield & 75 & @ & 800 \\
\hline 71 & Madison & 90 & $@$ & 1100 & 19 & Northumberland & 75 & @ & 1200 \\
\hline 196 & Manchester & 70 & $@$ & 500 & 153 & Northwood & 80 & @ & 800 \\
\hline 228 & Marlborough & 80 & $@$ & 1300 & 166 & Nottingham & 65 & @ & 500 \\
\hline 167 & Marlow & 90 & $@$ & 1600 & 14 & Odell & 90 & @ & 1800 \\
\hline 35 & Martins Location & 100 & $@$ & 1300 & 95 & Orange & 90 & @ & 1500 \\
\hline 254 & Mason & 75 & @ & 1000 & 72 & Orford & 70 & $@$ & 1100 \\
\hline
\end{tabular}

96 Meredith

$80 @ 1000$

* These loads only apply at the elevations listed. For lower elevations reduce the load by $2.1 \mathrm{lb} / \mathrm{ft}^{2}$ for every $100 \mathrm{ft}$ of elevation difference. For higher elevations up to $2500 \mathrm{ft}$, increase the load by $2.1 \mathrm{lb} / \mathrm{ft}^{2}$ for every $100 \mathrm{ft}$ of elevation difference. Examples are presented in the text. Do not use this information above $2500 \mathrm{ft}$ : Conduct a site-specific snow load case study.

$\dagger \quad$ To convert $\mathrm{lb} / \mathrm{ft}^{2}$ to $\mathrm{kN} / \mathrm{m}^{2}$, multiply by 0.048 .

** To convert feet to meters, multiply by 0.305 . 
Table 1 (cont.). Ground snow load $\left(p_{\mathrm{g}}\right)$ at a specific elevation for all New Hampshire towns.

\begin{tabular}{|c|c|c|c|c|c|c|c|c|}
\hline $\begin{array}{c}\text { Map } \\
\text { no. }\end{array}$ & Town & $\begin{array}{c}p_{g}{ }^{*} \\
\left(\mathrm{lb} / \mathrm{ft}^{2}\right)^{\dagger}\end{array}$ & $\begin{array}{c}\text { Elevation } \\
(\mathrm{ft})^{\star *}\end{array}$ & $\begin{array}{c}\text { Map } \\
\text { no. }\end{array}$ & Town & $\underset{\left(\mathrm{Ib} / \mathrm{ft}^{2}\right)^{\dagger}}{p_{\mathrm{g}}{ }^{*}}$ & & $\begin{array}{c}\text { Elevation } \\
(\mathrm{ft})^{\star *}\end{array}$ \\
\hline 82 & Ossipee & 85 & 1000 & 150 & Somersworth & 60 & $@$ & 250 \\
\hline 259 & Pelham & 55 & 400 & 235 & South Hampton & 50 & @ & 200 \\
\hline 159 & Pembroke & 70 & 700 & 115 & Springfield & 95 & $@$ & 1500 \\
\hline 223 & Peterborough & 75 & 1000 & 18 & Stark & 80 & $@$ & 1200 \\
\hline 65 & Piermont & 75 & 1400 & 4 & Stewartstown & 90 & $@$ & 2000 \\
\hline 44 & Pinkhams Grant & 115 & 2000 & 177 & Stoddard & 90 & @ & 1600 \\
\hline 1 & Pittsburg & 80 & 1700 & 142 & Strafford & 80 & $@$ & 800 \\
\hline 143 & Pittsfield & 80 & 900 & 15 & Stratford & 70 & $@$ & 1100 \\
\hline 110 & Plainfield & 90 & 1300 & 193 & Stratham & 50 & $@$ & 150 \\
\hline 238 & Plaistow & 55 & 300 & 20 & Success & 100 & $@$ & 1600 \\
\hline 84 & Plymouth & 75 & 900 & 48 & Sugar Hill & 90 & $@$ & 1600 \\
\hline 182 & Portsmouth & 50 & 100 & 195 & Sullivan & 90 & $@$ & 1400 \\
\hline 27 & Randolph & 110 & 1900 & 128 & Sunapee & 90 & @ & 1400 \\
\hline 186 & Raymond & 60 & 500 & 191 & Surry & 80 & @ & 1100 \\
\hline 250 & Richmond & 65 & 1100 & 135 & Sutton & 85 & @ & 1100 \\
\hline 256 & Rindge & 80 & 1300 & 231 & Swanzey & 65 & $@$ & 800 \\
\hline 140 & Rochester & 70 & 500 & 74 & Tamworth & 85 & $@$ & 1000 \\
\hline 160 & Rollinsford & 60 & 200 & 237 & Temple & 85 & $@$ & 1300 \\
\hline 211 & Roxbury & 80 & 1300 & 36 & Thompson \& & 120 & $@$ & 2500 \\
\hline 77 & Rumney & 85 & 1300 & & Meserves Purchase & & & \\
\hline 192 & Rye & 50 & 100 & 66 & Thornton & 85 & $@$ & 1200 \\
\hline 246 & Salem & 55 & 300 & 124 & Tilton & 80 & $@$ & 900 \\
\hline 129 & Salisbury & 80 & 900 & 241 & Troy & 75 & $@$ & 1300 \\
\hline 111 & Sanbornton & 80 & 1000 & 89 & Tuftonboro & 85 & $@$ & 1100 \\
\hline 216 & Sandown & 60 & 400 & 146 & Unity & 90 & $@$ & 1500 \\
\hline 76 & Sandwich & 85 & 1100 & 98 & Wakefield & 95 & $@$ & 900 \\
\hline 46 & Sargents Purchase & 115 & 2000 & 173 & Walpole & 80 & $@$ & 1200 \\
\hline 233 & Seabrook & 50 & 100 & 137 & Warner & 80 & $@$ & 800 \\
\hline 5 & Second College Grant & 85 & 1500 & 69 & Warren & 80 & $@$ & 1300 \\
\hline 248 & Sharon & 80 & 1300 & 158 & Washington & 95 & $@$ & 1700 \\
\hline 29 & Shelburne & 90 & 800 & 68 & Waterville Valley & 105 & $@$ & 1800 \\
\hline
\end{tabular}

* These loads only apply at the elevations listed. For lower elevations reduce the load by $2.1 \mathrm{lb} / \mathrm{ft}^{2}$ for every $100 \mathrm{ft}$ of elevation difference. For higher elevations up to $2500 \mathrm{ft}$, increase the load by $2.1 \mathrm{lb} / \mathrm{ft}^{2}$ for every $100 \mathrm{ft}$ of elevation difference. Examples are presented in the text. Do not use this information above $2500 \mathrm{ft}$ : Conduct a site-specific snow load case study.

$\dagger \quad$ To convert $\mathrm{lb} / \mathrm{ft}^{2}$ to $\mathrm{kN} / \mathrm{m}^{2}$, multiply by 0.048 .

** To convert feet to meters, multiply by 0.305 . 
Table 1 (cont.). Ground snow load $\left(p_{\mathrm{g}}\right)$ at a specific elevation for all New Hampshire towns.

\begin{tabular}{|c|c|c|c|c|c|c|c|c|}
\hline $\begin{array}{c}\text { Map } \\
\text { no. }\end{array}$ & Town & $\begin{array}{c}p_{\mathrm{g}}{ }^{*} \\
\left(\mathrm{lb} / \mathrm{ft}^{2}\right)^{\dagger}\end{array}$ & $\begin{array}{c}\text { Elevation } \\
(\mathrm{ft})^{\star *}\end{array}$ & $\begin{array}{c}\text { Map } \\
\text { no. }\end{array}$ & Town & $\begin{array}{c}p_{g}{ }^{*} \\
\left(\mathrm{lb} / \mathrm{ft}^{2}\right)^{\dagger}\end{array}$ & & $\begin{array}{c}\text { Elevation } \\
(\mathrm{ft})^{* *}\end{array}$ \\
\hline 176 & Weare & 80 & 900 & 239 & Wilton & 75 & $@$ & 900 \\
\hline 141 & Webster & 75 & 700 & 245 & Winchester & 60 & @ & 700 \\
\hline 75 & Wentworth & 80 & 1200 & 247 & Windham & 60 & @ & 400 \\
\hline 10 & Wentworth Location & 80 & 1300 & 174 & Windsor & 85 & @ & 1200 \\
\hline 203 & Westmoreland & 65 & 800 & 101 & Wolfeboro & 90 & @ & 1000 \\
\hline 28 & Whitefield & 80 & 1400 & 62 & Woodstock & 85 & @ & 1200 \\
\hline
\end{tabular}

* These loads only apply at the elevations listed. For lower elevations reduce the load by $2.1 \mathrm{lb} / \mathrm{ft}^{2}$ for every $100 \mathrm{ft}$ of elevation difference. For higher elevations up to $2500 \mathrm{ft}$, increase the load by $2.1 \mathrm{lb} / \mathrm{ft}^{2}$ for every $100 \mathrm{ft}$ of elevation difference. Examples are presented in the text. Do not use this information above $2500 \mathrm{ft}$ : Conduct a site-specific snow load case study.

$\dagger \quad$ To convert $\mathrm{lb} / \mathrm{ft}^{2}$ to $\mathrm{kN} / \mathrm{m}^{2}$, multiply by 0.048 .

** To convert feet to meters, multiply by 0.305 .

\section{CONCLUSIONS}

On average, each of us devoted about 24 minutes to the analysis of each "town" (i.e., each case study). The average time for each case study increased to about 32 minutes when the times necessary to determine case study locations and elevations, prepare case study forms, and manage the process are considered. Since there were six of us and 259 towns, our total time for the analysis phase of this project was about 820 man-hours. When all aspects of this project are considered, our total time to complete the project was about 2000 man-hours.

The intercept of the line of best fit on a case study's all-values plot provided a good indication of our team answer in most cases, but in a few cases it was not a very good indication. Thus, simply using the all-values intercept is not recommended.

The three practicing structural engineers involved chose to modify the case study analytical procedure developed by CRREL, each in his own way. Nonetheless, when coupled with our anonymous feedback process, it was easy for us to reach a consensus in almost all cases. 
As shown in Figure 6 the log-normal extreme value distribution does not fit every data set that well. By setting limits on the $p_{\mathrm{g}} / p_{\max }$ ratio and filtering out stations with very low or high ratios, such problems can be reduced. Stations with $p_{\mathrm{g}} / p_{\max }$ ratios greater than about 1.5 were given little weight, and those with ratios above about 1.7 were largely discounted in our analysis. Stations with $p_{\mathrm{g}} / p_{\text {max }}$ ratios less than about 0.9 appear to create similar problems. Alternatively other extreme value distributions or fitting methods may be worth considering.

An elevation adjustment factor of $2.1 \mathrm{lb} / \mathrm{ft}^{2}$ per $100 \mathrm{ft}\left(0.33 \mathrm{kN} / \mathrm{m}^{2}\right.$ per 100 m) works well for New Hampshire to an elevation of about $2500 \mathrm{ft}$ (about 762 $\mathrm{m}$ ). At higher elevations, site-specific case studies are still needed to determine ground snow loads. The elevation adjustment factor used for New Hampshire should not be assumed to apply in other parts of the country.

The case study process involves a more detailed examination of an area than was achieved some years ago when the national snow load map was made at CRREL. Thus, the case study process can be expected to produce a more accurate ground snow load. Since these case studies have been done according to the requirements of ASCE 7-98, it is appropriate to use the values in this report for all places in New Hampshire. In other words, for places in New Hampshire where ground snow loads can be determined from the map in ASCE 7-98, the values in Table 1 supersede those values. Table 1 is being added to Commentary Section C7.2 of ASCE 7-02 to acknowledge the value of such case studies and to promote such work by others. While nothing in the Commentary of ASCE Standard 7 is mandatory, that information has been subjected to consensus review and is a valuable, physical portion of the Standard. Rejecting or ignoring any of the guidance in the Commentary incurs significant risks.

The ground snow loads presented in Table 1, like the loads presented in ASCE Standard 7, are minimum values. They may be increased by the user, if judged appropriate.

Another product of this study is an SENH letter to each "town" in New Hampshire providing the ground snow load and elevation values in Table 1 for that town. Each letter also indicates that the methodology we used to generate these values meets the requirements of ASCE Standard 7, so our values are appropriate to use where case studies are needed and they supercede the values on the ground snow load map in ASCE Standard 7 in places where ground snow loads are mapped. 


\section{RECOMMENDATIONS}

With the hope that structural engineering organizations and others in other states will conduct similar studies, we have discussed ways of simplifying the procedure we used for New Hampshire.

The elevation adjustment factor should be determined at the onset of any study. The filters we used in New Hampshire when developing our elevation adjustment factor [i.e., excluding stations with less than 15 years of record, an elevation over $2500 \mathrm{ft}(762 \mathrm{~m})$, or a $p_{\mathrm{g}} / p_{\max }$ ratio less than 0.9 or more than 1.7] are worth considering. The potential variability of an elevation adjustment factor across a state should be investigated and, if necessary, regionalized factors developed.

At least three people should independently do each case study. Our preference is for five or six. When the participants are from different parts of a state, the probability increases that valuable local knowledge will be incorporated into findings.

The anonymous feedback feature used in the New Hampshire study is extremely important to incorporate into future studies.

It may be possible to simplify the process we used in New Hampshire by reducing the number of case studies that are conducted. We expect that we could have done about as well in New Hampshire if we had done case studies not at the geographical center of each town but on a 10- to 12-mile (16- to 19-km) grid. For Vermont, now considering a similar project, this would reduce the number of case studies from close to 250 to about 100. If this is done, all case studies should be done at the same elevation. For Vermont an elevation of $1000 \mathrm{ft}(305 \mathrm{~m})$ has been suggested. By plotting such grid answers on a map of the state that also contains the boundaries of each town and drawing isolines, a value can be determined for each town. Using the elevation adjustment factor, this value can be converted to a rounded elevation somewhat below the upper buildable elevation in that town. Then a table similar to Table 1 in this report can be generated.

Not only could this more than cut the number of case studies needed by more than half, but it also could greatly reduce the "quad sheet" work to the determination of only one elevation (i.e., the upper buildable elevation) for each town. The need to determine the latitude and longitude of the geographical center of each town is also eliminated. 
These changes should reduce labor by about half without significantly reducing the quality of the product. Additional labor savings may be possible by using rapidly advancing geographic information system (GIS) software.

We expect that this approach will work westward up to, but not into, the Rocky Mountains. Other studies conducted in that area have shown that the elevation adjustment factor is non-linear, increasing significantly with elevation. Our approach would need to be modified to account for that non-linearity in much of the West. Because of the size of western states, the likelihood of regional variations in the elevation adjustment factor would require further study.

\section{LITERATURE CITED}

American Society of Civil Engineers (2000) Minimum design loads for buildings and other structures. ASCE Standard 7-98. Reston, VA.

Building Officials and Code Administrators International, Inc. (BOCA) (1993) The BOCA National Building Code/1993. Country Club Hills, IL.

Tobiasson, W., and A. Greatorex (1997) Database and methodology for conducting site specific snow load case studies for the United States. In Snow Engineering, Recent Advances. Proceedings of the Third International Conference on Snow Engineering, Sendai, Japan, 1996. Rotterdam: A.A. Balkema. http://www.crrel.usace.army.mil/techpub/CRREL_Reports/html_files/ Cat_A.html

Tobiasson, W., J. Buska, A. Greatorex, J. Tirey, J. Fisher, and S. Johnson (2000) Developing ground snow loads for New Hampshire. In Snow Engineering, Recent Advances and Developments. Proceedings of the Fourth International Conference on Snow Engineering, Trondheim, Norway, 2000. Rotterdam: A.A. Balkema. http://www.crrel.usace.army.mil/techpub/ CRREL_Reports/html_files/Cat_A.html 


\section{APPENDIX A. COORDINATES OF THE GEOGRAPHICAL CENTER AND ELEVATION INFORMATION FOR EACH TOWN IN NEW HAMPSHIRE.}

\begin{tabular}{|c|c|c|c|c|c|c|c|c|c|c|c|}
\hline Town & $\begin{array}{l}\text { Lati } \\
\text { (deg }\end{array}$ & $\begin{array}{l}\text { ude } \\
\text { min) }\end{array}$ & $\begin{array}{l}\text { Long } \\
\text { (deg }\end{array}$ & $\begin{array}{l}\text { itude } \\
\text { min) }\end{array}$ & $\begin{array}{l}\text { Minimum } \\
\text { elevation } \\
(\mathrm{ft})^{*}\end{array}$ & $\begin{array}{c}\text { Minimum } \\
\text { building } \\
\text { elevation } \\
(\mathrm{ft})^{*}\end{array}$ & $\begin{array}{c}\text { Low } \\
\text { elevation } \\
\text { limit of } \\
\text { most } \\
\text { buildings } \\
\text { (ft)* }^{*}\end{array}$ & $\begin{array}{c}\text { High } \\
\text { elevation } \\
\text { limit of } \\
\text { most } \\
\text { buildings } \\
\text { (ft)* }\end{array}$ & $\begin{array}{c}\text { Maximum } \\
\text { building } \\
\text { elevation } \\
\text { (ft)* }\end{array}$ & $\begin{array}{l}\text { Maximum } \\
\text { elevation } \\
(\mathrm{ft})^{*}\end{array}$ & $\begin{array}{c}\text { Case } \\
\text { study } \\
\text { elevation } \\
\text { (ft) }^{*}\end{array}$ \\
\hline Acworth & 43 & 13 & 72 & 18 & 650 & 660 & 720 & 1580 & 1590 & 1930 & 1500 \\
\hline Albany & 43 & 58 & 71 & 16 & 460 & 470 & 470 & 1300 & 1320 & 3480 & 1300 \\
\hline Alexandria & 43 & 38 & 71 & 50 & 480 & 500 & 500 & 1200 & 1370 & 2400 & 1100 \\
\hline Allenstown & 43 & 8 & 71 & 23 & 200 & 210 & 220 & 720 & 730 & 830 & 700 \\
\hline Alstead & 43 & 7 & 72 & 19 & 430 & 440 & 440 & 1400 & 1610 & 1800 & 1300 \\
\hline Alton & 43 & 28 & 71 & 15 & 500 & 510 & 510 & 1000 & 1160 & 1910 & 900 \\
\hline Amherst & 42 & 52 & 71 & 37 & 190 & 200 & 210 & 650 & 820 & 860 & 600 \\
\hline Andover & 43 & 27 & 71 & 48 & 500 & 520 & 600 & 850 & 1020 & 2290 & 900 \\
\hline Antrim & 43 & 3 & 71 & 59 & 600 & 620 & 650 & 1200 & 1300 & 2040 & 1000 \\
\hline Ashland & 43 & 43 & 71 & 38 & 460 & 480 & 520 & 900 & 1000 & 1390 & 800 \\
\hline Atkinson & 42 & 51 & 71 & 10 & 50 & 60 & 80 & 350 & 380 & 390 & 400 \\
\hline $\begin{array}{l}\text { Atkinson \& } \\
\text { Gilmanton } \\
\text { Academy Grant }\end{array}$ & 44 & 59 & 71 & 8 & 1380 & 1390 & 1390 & 1670 & 1670 & 2620 & 1600 \\
\hline Auburn & 42 & 59 & 71 & 21 & 250 & 260 & 260 & 480 & 550 & 580 & 500 \\
\hline Barnstead & 43 & 21 & 71 & 16 & 490 & 500 & 500 & 1000 & 1110 & 1200 & 900 \\
\hline Barrington & 43 & 13 & 71 & 3 & 140 & 140 & 150 & 470 & 500 & 610 & 500 \\
\hline Bartlett & 44 & 5 & 71 & 15 & 490 & 500 & 500 & 1250 & 1250 & 3370 & 1200 \\
\hline Bath & 44 & 11 & 72 & 0 & 420 & 440 & 450 & 1000 & 1180 & 1980 & 1000 \\
\hline Beans Grant & 44 & 13 & 71 & 23 & 1600 & NA & NA & NA & NA & 4310 & 1800 \\
\hline Beans Purchase & 44 & 17 & 71 & 7 & 900 & 3970 & 3970 & 3970 & 3970 & 4830 & 2000 \\
\hline Bedford & 42 & 57 & 71 & 32 & 110 & 140 & 140 & 700 & 780 & 830 & 700 \\
\hline Belmont & 43 & 28 & 71 & 28 & 460 & 470 & 470 & 950 & 1110 & 1360 & 900 \\
\hline Bennington & 43 & 0 & 71 & 54 & 600 & 650 & 700 & 970 & 1060 & 2020 & 1000 \\
\hline Benton & 44 & 2 & 71 & 52 & 800 & 820 & 820 & 1660 & 1660 & 4800 & 1600 \\
\hline Berlin & 44 & 29 & 71 & 16 & 900 & 910 & 940 & 1850 & 1930 & 3900 & 1600 \\
\hline Bethlehem & 44 & 16 & 71 & 36 & 870 & 900 & 900 & 1820 & 2200 & 4760 & 1800 \\
\hline Boscawen & 43 & 19 & 71 & 40 & 260 & 260 & 300 & 750 & 850 & 920 & 700 \\
\hline Bow & 43 & 8 & 71 & 32 & 200 & 200 & 230 & 900 & 910 & 910 & 800 \\
\hline Bradford & 43 & 14 & 71 & 59 & 630 & 640 & 640 & 1200 & 1270 & 2100 & 1200 \\
\hline Brentwood & 42 & 59 & 71 & 2 & 50 & 70 & 80 & 250 & 260 & 270 & 250 \\
\hline Bridgewater & 43 & 40 & 71 & 41 & 460 & 470 & 480 & 1200 & 1640 & 1910 & 1000 \\
\hline Bristol & 43 & 37 & 71 & 43 & 320 & 410 & 440 & 1080 & 1080 & 1800 & 1000 \\
\hline Brookfield & 43 & 32 & 71 & 5 & 520 & 520 & 540 & 800 & 1480 & 1870 & 800 \\
\hline Brookline & 42 & 45 & 71 & 40 & 230 & 240 & 250 & 500 & 670 & 810 & 500 \\
\hline Cambridge & 44 & 40 & 71 & 6 & 1180 & 1250 & 1250 & 1300 & 1320 & 2780 & 1300 \\
\hline Campton & 43 & 50 & 71 & 40 & 480 & 530 & 540 & 1400 & 1800 & 2550 & 1300 \\
\hline Canaan & 43 & 41 & 72 & 2 & 800 & 810 & 810 & 1200 & 1440 & 2220 & 1200 \\
\hline Candia & 43 & 3 & 71 & 19 & 210 & 220 & 220 & 700 & 710 & 940 & 700 \\
\hline Canterbury & 43 & 21 & 71 & 32 & 250 & 260 & 280 & 900 & 1100 & 1380 & 900 \\
\hline Carroll & 44 & 17 & 71 & 30 & 1060 & 1140 & 1180 & 1700 & 1900 & 3540 & 1700 \\
\hline Center Harbor & 43 & 42 & 71 & 31 & 500 & 510 & 510 & 950 & 950 & 1120 & 900 \\
\hline Chandlers Purchase & 44 & 16 & 71 & 22 & 2320 & 2570 & 2570 & 2570 & 2570 & 4760 & 2500 \\
\hline
\end{tabular}

* To convert feet to meters, multiply by 0.305 .

NA means there are essentially no buildings in this town. 


\begin{tabular}{|c|c|c|c|c|c|c|c|c|c|c|c|}
\hline Town & $\begin{array}{l}\text { Lati } \\
\text { (deg }\end{array}$ & $\begin{array}{l}\text { ude } \\
\text { min) }\end{array}$ & $\begin{array}{l}\text { Long } \\
\text { (deg }\end{array}$ & $\begin{array}{l}\text { tude } \\
\text { min) }\end{array}$ & $\begin{array}{l}\text { Minimum } \\
\text { elevation } \\
(\mathrm{ft})^{*}\end{array}$ & $\begin{array}{c}\text { Minimum } \\
\text { building } \\
\text { elevation } \\
\text { (ft)* }\end{array}$ & $\begin{array}{c}\text { Low } \\
\text { elevation } \\
\text { limit of } \\
\text { most } \\
\text { buildings } \\
\text { (ft)* }\end{array}$ & $\begin{array}{c}\text { High } \\
\text { elevation } \\
\text { limit of } \\
\text { most } \\
\text { buildings } \\
\text { (ft) }^{*}\end{array}$ & $\begin{array}{c}\text { Maximum } \\
\text { building } \\
\text { elevation } \\
\text { (ft)* }\end{array}$ & $\begin{array}{l}\text { Maximum } \\
\text { elevation } \\
(\mathrm{ft})^{*}\end{array}$ & $\begin{array}{c}\text { Case } \\
\text { study } \\
\text { elevation } \\
\text { (ft)* }^{*}\end{array}$ \\
\hline Charlestown & 43 & 14 & 72 & 24 & 290 & 300 & 300 & 1300 & 1320 & 1680 & 1100 \\
\hline Chatham & 44 & 9 & 71 & 3 & 390 & 390 & 390 & 540 & 900 & 3560 & 500 \\
\hline Chester & 42 & 58 & 71 & 15 & 170 & 180 & 180 & 530 & 550 & 640 & 500 \\
\hline Chesterfield & 42 & 53 & 72 & 27 & 220 & 230 & 240 & 1100 & 1160 & 1430 & 1000 \\
\hline Chichester & 43 & 15 & 71 & 24 & 340 & 350 & 360 & 800 & 980 & 1010 & 700 \\
\hline Claremont & 43 & 23 & 72 & 20 & 290 & 300 & 340 & 1200 & 1260 & 1960 & 1100 \\
\hline Clarksville & 45 & 1 & 71 & 19 & 1100 & 1100 & 1100 & 2000 & 2180 & 3080 & 2000 \\
\hline Colebrook & 44 & 54 & 71 & 25 & 1000 & 1040 & 1040 & 1770 & 1920 & 2760 & 1600 \\
\hline Columbia & 44 & 50 & 71 & 28 & 920 & 970 & 1000 & 1700 & 1720 & 3720 & 1600 \\
\hline Concord & 43 & 14 & 71 & 34 & 200 & 220 & 230 & 610 & 710 & 860 & 600 \\
\hline Conway & 44 & 1 & 71 & 4 & 400 & 400 & 420 & 900 & 1000 & 2370 & 900 \\
\hline Cornish & 43 & 28 & 72 & 19 & 300 & 310 & 330 & 1180 & 1550 & 2320 & 1100 \\
\hline Crawfords Purchase & 44 & 16 & 71 & 24 & 1610 & NA & NA & NA & NA & 2890 & 1800 \\
\hline Croydon & 43 & 27 & 72 & 12 & 780 & 790 & 790 & 1150 & 1230 & 2760 & 1200 \\
\hline Cutts Grant & 44 & 12 & 71 & 20 & 1320 & NA & NA & NA & NA & 4720 & 1700 \\
\hline Dalton & 44 & 23 & 71 & 41 & 790 & 850 & 890 & 1480 & 1810 & 2150 & 1300 \\
\hline Danbury & 43 & 31 & 71 & 52 & 660 & 690 & 740 & 1000 & 1330 & 2320 & 1000 \\
\hline Danville & 42 & 56 & 71 & 7 & 140 & 150 & 150 & 310 & 330 & 350 & 300 \\
\hline Deerfield & 43 & 8 & 71 & 15 & 210 & 220 & 230 & 770 & 880 & 1080 & 700 \\
\hline Deering & 43 & 4 & 71 & 51 & 600 & 600 & 600 & 1270 & 1270 & 1550 & 1200 \\
\hline Derry & 42 & 53 & 71 & 17 & 200 & 200 & 210 & 570 & 580 & 600 & 600 \\
\hline Dixs Grant & 44 & 55 & 71 & 12 & 1520 & 1580 & 1580 & 1900 & 2180 & 3280 & 1700 \\
\hline Dixville & 44 & 53 & 71 & 16 & 1360 & 1600 & 1600 & 1900 & 1900 & 3440 & 1900 \\
\hline Dorchester & 43 & 46 & 71 & 59 & 870 & 950 & 950 & 1400 & 1700 & 3190 & 1400 \\
\hline Dover & 43 & 12 & 70 & 53 & 0 & 10 & 10 & 220 & 280 & 300 & 200 \\
\hline Dublin & 42 & 53 & 72 & 5 & 920 & 960 & 980 & 1600 & 1780 & 2840 & 1600 \\
\hline Dummer & 44 & 40 & 71 & 15 & 980 & 1000 & 1000 & 1400 & 1550 & 2300 & 1400 \\
\hline Dunbarton & 43 & 6 & 71 & 37 & 350 & 350 & 380 & 860 & 890 & 920 & 800 \\
\hline Durham & 43 & 7 & 70 & 56 & 0 & 10 & 10 & 140 & 140 & 280 & 150 \\
\hline East Kingston & 42 & 56 & 71 & 1 & 40 & 70 & 100 & 200 & 260 & 310 & 200 \\
\hline Easton & 44 & 8 & 71 & 47 & 1000 & 1020 & 1020 & 1380 & 1380 & 3920 & 1400 \\
\hline Eaton & 43 & 54 & 71 & 3 & 440 & 450 & 470 & 1050 & 1430 & 1650 & 1000 \\
\hline Effingham & 43 & 45 & 71 & 3 & 380 & 400 & 400 & 650 & 960 & 1880 & 600 \\
\hline Ellsworth & 43 & 54 & 71 & 46 & 1040 & 1080 & 1100 & 1400 & 1440 & 3310 & 1400 \\
\hline Enfield & 43 & 36 & 72 & 7 & 750 & 760 & 760 & 1350 & 1460 & 2110 & 1300 \\
\hline Epping & 43 & 3 & 71 & 5 & 90 & 100 & 100 & 280 & 340 & 470 & 300 \\
\hline Epsom & 43 & 13 & 71 & 20 & 290 & 300 & 300 & 800 & 900 & 1410 & 800 \\
\hline Errol & 44 & 46 & 71 & 8 & 1190 & 1230 & 1250 & 1600 & 1630 & 2280 & 1600 \\
\hline Ervings Location & 44 & 48 & 71 & 21 & 2020 & NA & NA & NA & NA & 2830 & 2100 \\
\hline Exeter & 42 & 59 & 70 & 58 & 20 & 20 & 20 & 230 & 240 & 250 & 200 \\
\hline Farmington & 43 & 22 & 71 & 5 & 240 & 260 & 260 & 850 & 1110 & 1360 & 800 \\
\hline Fitzwilliam & 42 & 46 & 72 & 9 & 880 & 890 & 890 & 1300 & 1340 & 1890 & 1300 \\
\hline Francestown & 42 & 59 & 71 & 49 & 590 & 590 & 600 & 1200 & 1340 & 2070 & 1100 \\
\hline Franconia & 44 & 11 & 71 & 40 & 900 & 910 & 910 & 2000 & 4040 & 5240 & 1700 \\
\hline Franklin & 43 & 27 & 71 & 39 & 250 & 280 & 350 & 700 & 750 & 1300 & 700 \\
\hline Freedom & 43 & 49 & 71 & 4 & 380 & 400 & 400 & 1100 & 1260 & 1810 & 1000 \\
\hline
\end{tabular}

* To convert feet to meters, multiply by 0.305 .

NA means there are essentially no buildings in this town. 


\begin{tabular}{|c|c|c|c|c|c|c|c|c|c|c|c|}
\hline Town & $\begin{array}{l}\text { Latit } \\
\text { (deg }\end{array}$ & $\begin{array}{l}\text { ude } \\
\text { min) }\end{array}$ & $\begin{array}{l}\text { Long } \\
\text { (deg }\end{array}$ & $\begin{array}{l}\text { tude } \\
\text { min) }\end{array}$ & $\begin{array}{l}\text { Minimum } \\
\text { elevation } \\
\text { (ft)* }\end{array}$ & $\begin{array}{c}\text { Minimum } \\
\text { building } \\
\text { elevation } \\
\text { (ft)* }^{*}\end{array}$ & $\begin{array}{c}\text { Low } \\
\text { elevation } \\
\text { limit of } \\
\text { most } \\
\text { buildings } \\
\text { (ft)* }\end{array}$ & $\begin{array}{c}\text { High } \\
\text { elevation } \\
\text { limit of } \\
\text { most } \\
\text { buildings } \\
\text { (ft)* }\end{array}$ & $\begin{array}{l}\text { Maximum } \\
\text { building } \\
\text { elevation } \\
\text { (ft)* }\end{array}$ & $\begin{array}{l}\text { Maximum } \\
\text { elevation } \\
(\mathrm{ft})^{*}\end{array}$ & $\begin{array}{c}\text { Case } \\
\text { study } \\
\text { elevation } \\
\text { (ft) }^{*}\end{array}$ \\
\hline Fremont & 42 & 59 & 71 & 7 & 120 & 130 & 130 & 240 & 270 & 320 & 250 \\
\hline Gilford & 43 & 34 & 71 & 23 & 500 & 510 & 510 & 1300 & 1320 & 2380 & 1200 \\
\hline Gilmanton & 43 & 26 & 71 & 22 & 530 & 540 & 540 & 1200 & 1240 & 1940 & 1100 \\
\hline Gilsum & 43 & 3 & 72 & 16 & 670 & 690 & 720 & 1300 & 1500 & 1640 & 1200 \\
\hline Goffstown & 43 & 1 & 71 & 34 & 160 & 160 & 160 & 800 & 1260 & 1320 & 800 \\
\hline Gorham & 44 & 23 & 71 & 12 & 740 & 760 & 760 & 1420 & 1420 & 3020 & 1400 \\
\hline Goshen & 43 & 17 & 72 & 7 & 940 & 950 & 950 & 1450 & 1730 & 2530 & 1400 \\
\hline Grafton & 43 & 35 & 71 & 58 & 830 & 840 & 840 & 1500 & 1600 & 2180 & 1400 \\
\hline Grantham & 43 & 31 & 72 & 9 & 920 & 930 & 930 & 1400 & 1480 & 2650 & 1400 \\
\hline Greenfield & 42 & 57 & 71 & 52 & 670 & 700 & 700 & 1300 & 1330 & 2280 & 1100 \\
\hline Greenland & 43 & 2 & 70 & 50 & 10 & 10 & 10 & 110 & 110 & 140 & 100 \\
\hline Greens Grant & 44 & 18 & 71 & 13 & 1320 & 1580 & 1580 & 1700 & 1700 & 2540 & 1700 \\
\hline Greenville & 42 & 46 & 71 & 48 & 660 & 720 & 840 & 960 & 1050 & 1120 & 1000 \\
\hline Groton & 43 & 44 & 71 & 52 & 620 & 620 & 620 & 1300 & 1560 & 2310 & 1200 \\
\hline Hadleys Purchase & 44 & 7 & 71 & 20 & 880 & NA & NA & NA & NA & 3160 & 1500 \\
\hline Hales Location & 44 & 2 & 71 & 10 & 470 & 500 & 500 & 700 & 620 & 1440 & 800 \\
\hline Hampstead & 42 & 53 & 71 & 10 & 180 & 200 & 210 & 330 & 340 & 400 & 300 \\
\hline Hampton & 42 & 56 & 70 & 50 & 0 & 10 & 10 & 130 & 140 & 150 & 150 \\
\hline Hampton Falls & 42 & 55 & 70 & 53 & 0 & 10 & 10 & 120 & 160 & 230 & 150 \\
\hline Hancock & 42 & 59 & 72 & 0 & 680 & 680 & 690 & 1400 & 1440 & 1990 & 1300 \\
\hline Hanover & 43 & 43 & 72 & 12 & 390 & 400 & 400 & 1440 & 1590 & 2300 & 1300 \\
\hline Harrisville & 42 & 57 & 72 & 6 & 950 & 950 & 970 & 1500 & 1600 & 1910 & 1500 \\
\hline Harts Location & 44 & 8 & 71 & 22 & 760 & 770 & 770 & 1320 & 1480 & 3920 & 1300 \\
\hline Haverhill & 44 & 5 & 71 & 59 & 400 & 420 & 450 & 1350 & 1360 & 2320 & 1200 \\
\hline Hebron & 43 & 42 & 71 & 48 & 590 & 600 & 600 & 900 & 1000 & 2230 & 900 \\
\hline Henniker & 43 & 11 & 71 & 49 & 400 & 410 & 410 & 1100 & 1200 & 1550 & 1000 \\
\hline Hill & 43 & 32 & 71 & 46 & 320 & 330 & 400 & 1100 & 1250 & 1900 & 1100 \\
\hline Hillsborough & 43 & 9 & 71 & 56 & 550 & 570 & 600 & 1100 & 1100 & 1750 & 1000 \\
\hline Hinsdale & 42 & 48 & 72 & 30 & 200 & 220 & 230 & 760 & 1160 & 1370 & 700 \\
\hline Holderness & 43 & 45 & 71 & 35 & 480 & 480 & 480 & 1000 & 1210 & 2080 & 1000 \\
\hline Hollis & 42 & 45 & 71 & 35 & 160 & 180 & 180 & 450 & 570 & 820 & 500 \\
\hline Hooksett & 43 & 4 & 71 & 26 & 180 & 190 & 190 & 670 & 730 & 900 & 600 \\
\hline Hopkinton & 43 & 12 & 71 & 42 & 350 & 360 & 360 & 840 & 840 & 920 & 800 \\
\hline Hudson & 42 & 46 & 71 & 25 & 90 & 100 & 110 & 380 & 430 & 520 & 400 \\
\hline Jackson & 44 & 11 & 71 & 12 & 720 & 730 & 730 & 1950 & 1950 & 3870 & 1800 \\
\hline Jaffrey & 42 & 50 & 72 & 3 & 860 & 870 & 900 & 1350 & 1520 & 3150 & 1300 \\
\hline Jefferson & 44 & 24 & 71 & 28 & 1030 & 1040 & 1040 & 1970 & 2110 & 3900 & 1700 \\
\hline Keene & 42 & 57 & 72 & 18 & 470 & 480 & 480 & 900 & 1030 & 1380 & 900 \\
\hline Kensington & 42 & 56 & 70 & 57 & 30 & 40 & 40 & 230 & 260 & 300 & 200 \\
\hline Kilkenny & 44 & 30 & 71 & 24 & 1710 & NA & NA & NA & NA & 4080 & 1700 \\
\hline Kingston & 42 & 55 & 71 & 4 & 100 & 120 & 120 & 220 & 250 & 340 & 200 \\
\hline Laconia & 43 & 34 & 71 & 28 & 480 & 490 & 490 & 900 & 940 & 960 & 900 \\
\hline Lancaster & 44 & 29 & 71 & 33 & 850 & 850 & 850 & 1280 & 1540 & 3290 & 1300 \\
\hline Landaff & 44 & 9 & 71 & 53 & 560 & 580 & 580 & 1400 & 1640 & 2330 & 1300 \\
\hline Langdon & 43 & 10 & 72 & 23 & 300 & 320 & 450 & 1100 & 1280 & 1340 & 1000 \\
\hline Lebanon & 43 & 38 & 72 & 15 & 320 & 340 & 360 & 1400 & 1400 & 1660 & 1200 \\
\hline
\end{tabular}

* To convert feet to meters, multiply by 0.305 .

NA means there are essentially no buildings in this town. 


\begin{tabular}{|c|c|c|c|c|c|c|c|c|c|c|c|}
\hline Town & \multicolumn{2}{|c|}{$\begin{array}{l}\text { Latitude } \\
\text { (deg min) }\end{array}$} & \multicolumn{2}{|c|}{$\begin{array}{r}\text { Longitude } \\
\text { (deg min) }\end{array}$} & \multirow{2}{*}{$\begin{array}{c}\begin{array}{c}\text { Minimum } \\
\text { elevation } \\
(\mathrm{ft})^{*}\end{array} \\
60\end{array}$} & \multirow{2}{*}{\multicolumn{2}{|c|}{$\begin{array}{cc}\begin{array}{c}\text { Low } \\
\text { Minimum } \\
\text { building } \\
\text { elevation } \\
\text { elevation } \\
\text { (ft)* }\end{array} & \begin{array}{c}\text { limit of } \\
\text { buildings } \\
(\mathrm{ft})^{*}\end{array} \\
70 & 80\end{array}$}} & \multirow[t]{2}{*}{$\begin{array}{l}\text { High } \\
\text { elevation } \\
\text { limit of } \\
\text { most } \\
\text { buildings } \\
\text { (ft)* } \\
190\end{array}$} & \multirow[t]{2}{*}{$\begin{array}{c}\begin{array}{c}\text { Maximum } \\
\text { building } \\
\text { elevation } \\
(\mathrm{ft})^{*}\end{array} \\
210\end{array}$} & \multirow{2}{*}{$\begin{array}{c}\begin{array}{c}\text { Maximum } \\
\text { elevation } \\
(\mathrm{ft})^{*}\end{array} \\
270\end{array}$} & \multirow{2}{*}{$\begin{array}{c}\text { Case } \\
\text { study } \\
\text { elevation } \\
(f t)^{*} \\
200\end{array}$} \\
\hline Lee & 43 & 7 & 71 & 0 & & & & & & & \\
\hline Lempster & 43 & 14 & 72 & 11 & 1020 & 1020 & 1020 & 1600 & 1810 & 2330 & 1600 \\
\hline Lincoln & 44 & 6 & 71 & 35 & 760 & 780 & 780 & 1400 & 2730 & 4700 & 1400 \\
\hline Lisbon & 44 & 14 & 71 & 52 & 560 & 580 & 600 & 1100 & 1430 & 1600 & 1100 \\
\hline Litchfield & 42 & 51 & 71 & 27 & 100 & 110 & 120 & 230 & 280 & 360 & 250 \\
\hline Littleton & 44 & 19 & 71 & 48 & 650 & 700 & 700 & 1300 & 1670 & 2200 & 1200 \\
\hline Livermore & 44 & 2 & 71 & 29 & 1280 & NA & NA & NA & NA & 4680 & 1500 \\
\hline Londonderry & 42 & 53 & 71 & 24 & 140 & 150 & 160 & 480 & 500 & 530 & 500 \\
\hline Loudon & 43 & 19 & 71 & 27 & 320 & 320 & 360 & 900 & 1020 & 1040 & 900 \\
\hline $\begin{array}{l}\text { Low \& Burbanks } \\
\text { Grant }\end{array}$ & 44 & 19 & 71 & 22 & 1530 & NA & NA & NA & NA & 5550 & 1800 \\
\hline Lyman & 44 & 16 & 71 & 57 & 650 & 650 & 650 & 1200 & 1350 & 2300 & 1200 \\
\hline Lyme & 43 & 49 & 72 & 8 & 390 & 400 & 400 & 1200 & 1380 & 3240 & 1100 \\
\hline Lyndeborough & 42 & 54 & 71 & 47 & 260 & 310 & 450 & 1150 & 1320 & 1780 & 1000 \\
\hline Madbury & 43 & 11 & 70 & 57 & 0 & 10 & 40 & 200 & 280 & 330 & 200 \\
\hline Madison & 43 & 54 & 71 & 9 & 440 & 440 & 450 & 1200 & 1240 & 1560 & 1100 \\
\hline Manchester & 42 & 59 & 71 & 27 & 100 & 120 & 130 & 480 & 510 & 570 & 500 \\
\hline Marlborough & 42 & 54 & 72 & 11 & 630 & 640 & 640 & 1300 & 1300 & 1400 & 1300 \\
\hline Marlow & 43 & 8 & 72 & 13 & 1060 & 1100 & 1200 & 1600 & 1700 & 1960 & 1600 \\
\hline Martins Location & 44 & 20 & 71 & 13 & 1130 & 1230 & 1230 & 1280 & 1280 & 2600 & 1300 \\
\hline Mason & 42 & 45 & 71 & 45 & 350 & 380 & 400 & 1000 & 1040 & 1050 & 1000 \\
\hline Meredith & 43 & 38 & 71 & 30 & 480 & 490 & 490 & 1070 & 1230 & 1410 & 1000 \\
\hline Merrimack & 42 & 51 & 71 & 31 & 100 & 120 & 120 & 430 & 480 & 510 & 400 \\
\hline Middleton & 43 & 29 & 71 & 4 & 480 & 500 & 520 & 800 & 900 & 1670 & 800 \\
\hline Milan & 44 & 34 & 71 & 12 & 980 & 1000 & 1000 & 1600 & 1680 & 2810 & 1500 \\
\hline Milford & 42 & 49 & 71 & 40 & 210 & 230 & 230 & 630 & 630 & 810 & 600 \\
\hline Millsfield & 44 & 46 & 71 & 16 & 1300 & 1300 & 1300 & 1730 & 1830 & 3470 & 1700 \\
\hline Milton & 43 & 27 & 71 & 0 & 250 & 260 & 300 & 860 & 990 & 1080 & 800 \\
\hline Monroe & 44 & 17 & 72 & 1 & 440 & 460 & 500 & 950 & 1040 & 2300 & 1000 \\
\hline Mont Vernon & 42 & 54 & 71 & 41 & 340 & 440 & 450 & 850 & 880 & 990 & 900 \\
\hline Moultonborough & 43 & 44 & 71 & 23 & 500 & 510 & 510 & 950 & 950 & 2990 & 900 \\
\hline Nashua & 42 & 46 & 71 & 29 & 90 & 110 & 110 & 420 & 420 & 420 & 400 \\
\hline Nelson & 42 & 59 & 72 & 8 & 1080 & 1140 & 1220 & 1500 & 1710 & 2240 & 1500 \\
\hline New Boston & 42 & 58 & 71 & 41 & 300 & 300 & 300 & 800 & 920 & 1280 & 800 \\
\hline New Castle & 43 & 4 & 70 & 43 & 0 & 10 & 10 & 40 & 50 & 60 & 50 \\
\hline New Durham & 43 & 28 & 71 & 8 & 400 & 420 & 540 & 1000 & 1240 & 1700 & 900 \\
\hline New Hampton & 43 & 37 & 71 & 37 & 320 & 470 & 470 & 1060 & 1060 & 1840 & 1000 \\
\hline New Ipswich & 42 & 45 & 71 & 52 & 820 & 830 & 850 & 1300 & 1420 & 1880 & 1300 \\
\hline New London & 43 & 25 & 71 & 59 & 760 & 780 & 780 & 1380 & 1420 & 1760 & 1400 \\
\hline Newbury & 43 & 19 & 72 & 2 & 680 & 680 & 680 & 1300 & 1410 & 2730 & 1300 \\
\hline Newfields & 43 & 2 & 70 & 58 & 10 & 10 & 10 & 140 & 140 & 240 & 150 \\
\hline Newington & 43 & 6 & 70 & 50 & 0 & 10 & 10 & 100 & 100 & 100 & 100 \\
\hline Newmarket & 43 & 4 & 70 & 58 & 10 & 10 & 20 & 170 & 180 & 280 & 200 \\
\hline Newport & 43 & 22 & 72 & 12 & 590 & 630 & 650 & 1200 & 1420 & 1880 & 1200 \\
\hline Newton & 42 & 52 & 71 & 3 & 90 & 100 & 110 & 240 & 260 & 280 & 250 \\
\hline North Hampton & 42 & 58 & 70 & 50 & 0 & 10 & 10 & 120 & 120 & 160 & 100 \\
\hline
\end{tabular}

* To convert feet to meters, multiply by 0.305 .

NA means there are essentially no buildings in this town. 


\begin{tabular}{|c|c|c|c|c|c|c|c|c|c|c|c|}
\hline \multirow{2}{*}{$\begin{array}{c}\text { Town } \\
\text { Northfield }\end{array}$} & \multicolumn{2}{|c|}{$\begin{array}{l}\text { Latitude } \\
\text { (deg min) }\end{array}$} & \multicolumn{2}{|c|}{$\begin{array}{l}\text { Longitude } \\
\text { (deg min) }\end{array}$} & \multirow{2}{*}{$\begin{array}{c}\begin{array}{c}\text { Minimum } \\
\text { elevation } \\
(f t)^{*}\end{array} \\
260\end{array}$} & \multirow{2}{*}{$\begin{array}{c}\begin{array}{c}\text { Minimum } \\
\text { building } \\
\text { elevation } \\
(f t)^{*}\end{array} \\
280\end{array}$} & \multirow[t]{2}{*}{$\begin{array}{c}\text { Low } \\
\text { elevation } \\
\text { limit of } \\
\text { most } \\
\text { buildings } \\
\text { (ft)* }^{*} \\
400\end{array}$} & \multirow[t]{2}{*}{$\begin{array}{c}\text { High } \\
\text { elevation } \\
\text { limit of } \\
\text { most } \\
\text { buildings } \\
\text { (ft)* }^{*} \\
860\end{array}$} & \multirow[t]{2}{*}{$\begin{array}{c}\begin{array}{c}\text { Maximum } \\
\text { building } \\
\text { elevation } \\
(\mathrm{ft})^{*}\end{array} \\
1000\end{array}$} & \multirow{2}{*}{$\begin{array}{c}\begin{array}{c}\text { Maximum } \\
\text { elevation } \\
(\mathrm{ft})^{*}\end{array} \\
1500\end{array}$} & \multirow{2}{*}{$\begin{array}{c}\begin{array}{c}\text { Case } \\
\text { study } \\
\text { elevation } \\
(f t)^{*}\end{array} \\
800\end{array}$} \\
\hline & 43 & 25 & 71 & 35 & & & & & & & \\
\hline Northumberland & 44 & 35 & 71 & 31 & 850 & 870 & 870 & 1300 & 1400 & 2650 & 1200 \\
\hline Northwood & 43 & 13 & 71 & 13 & 330 & 380 & 450 & 800 & 860 & 1150 & 800 \\
\hline Nottingham & 43 & 8 & 71 & 7 & 120 & 140 & 150 & 550 & 600 & 980 & 500 \\
\hline Odell & 44 & 43 & 71 & 22 & 1480 & 1600 & 1600 & 2350 & 2350 & 3660 & 1800 \\
\hline Orange & 43 & 40 & 71 & 57 & 960 & 980 & 1000 & 1700 & 1850 & 3120 & 1500 \\
\hline Orford & 43 & 54 & 72 & 5 & 400 & 400 & 400 & 1200 & 1380 & 2910 & 1100 \\
\hline Ossipee & 43 & 44 & 71 & 9 & 410 & 410 & 410 & 1000 & 1100 & 1780 & 1000 \\
\hline Pelham & 42 & 44 & 71 & 19 & 130 & 130 & 130 & 400 & 530 & 570 & 400 \\
\hline Pembroke & 43 & 11 & 71 & 27 & 200 & 200 & 230 & 750 & 830 & 1000 & 700 \\
\hline Peterborough & 42 & 53 & 71 & 57 & 700 & 700 & 700 & 1000 & 1200 & 2200 & 1000 \\
\hline Piermont & 43 & 59 & 72 & 2 & 400 & 410 & 460 & 1350 & 1400 & 2720 & 1400 \\
\hline Pinkhams Grant & 44 & 16 & 71 & 15 & 1610 & 1960 & 1960 & 2030 & 2030 & 3050 & 2000 \\
\hline Pittsburg & 45 & 9 & 71 & 15 & 1000 & 1100 & 1100 & 1800 & 2060 & 3380 & 1700 \\
\hline Pittsfield & 43 & 18 & 71 & 18 & 350 & 400 & 460 & 960 & 1140 & 1330 & 900 \\
\hline Plainfield & 43 & 33 & 72 & 17 & 320 & 340 & 380 & 1300 & 1480 & 2650 & 1300 \\
\hline Plaistow & 42 & 51 & 71 & 6 & 40 & 50 & 60 & 270 & 280 & 380 & 300 \\
\hline Plymouth & 43 & 45 & 71 & 43 & 480 & 490 & 490 & 900 & 1120 & 2190 & 900 \\
\hline Portsmouth & 43 & 3 & 70 & 47 & 0 & 10 & 10 & 80 & 100 & 100 & 100 \\
\hline Randolph & 44 & 24 & 71 & 19 & 1380 & 1380 & 1380 & 1900 & 1910 & 3950 & 1900 \\
\hline Raymond & 43 & 2 & 71 & 12 & 160 & 160 & 170 & 480 & 480 & 620 & 500 \\
\hline Richmond & 42 & 46 & 72 & 17 & 500 & 540 & 600 & 1180 & 1300 & 1620 & 1100 \\
\hline Rindge & 42 & 45 & 72 & 0 & 910 & 910 & 920 & 1350 & 1380 & 1500 & 1300 \\
\hline Rochester & 43 & 18 & 70 & 59 & 110 & 130 & 150 & 480 & 560 & 580 & 500 \\
\hline Rollinsford & 43 & 13 & 70 & 50 & 10 & 20 & 40 & 180 & 210 & 300 & 200 \\
\hline Roxbury & 42 & 57 & 72 & 12 & 590 & 600 & 600 & 1300 & 1450 & 1630 & 1300 \\
\hline Rumney & 43 & 50 & 71 & 48 & 440 & 480 & 480 & 1320 & 1320 & 2880 & 1300 \\
\hline Rye & 43 & 1 & 70 & 45 & 0 & 10 & 10 & 120 & 140 & 150 & 100 \\
\hline Salem & 42 & 47 & 71 & 13 & 110 & 110 & 110 & 280 & 300 & 380 & 300 \\
\hline Salisbury & 43 & 23 & 71 & 46 & 570 & 600 & 660 & 900 & 900 & 1900 & 900 \\
\hline Sanbornton & 43 & 31 & 71 & 36 & 300 & 420 & 480 & 900 & 1250 & 2000 & 1000 \\
\hline Sandown & 42 & 56 & 71 & 11 & 180 & 190 & 190 & 400 & 430 & 500 & 400 \\
\hline Sandwich & 43 & 50 & 71 & 27 & 560 & 570 & 570 & 1160 & 1760 & 3960 & 1100 \\
\hline Sargents Purchase & 44 & 14 & 71 & 17 & 1240 & 3810 & 3810 & 6290 & 6290 & 6290 & 2000 \\
\hline Seabrook & 42 & 53 & 70 & 52 & 0 & 10 & 10 & 100 & 130 & 220 & 100 \\
\hline $\begin{array}{l}\text { Second College } \\
\text { Grant }\end{array}$ & 44 & 55 & 71 & 6 & 1200 & 1300 & 1300 & 1400 & 1400 & 2820 & 1500 \\
\hline Sharon & 42 & 49 & 71 & 56 & 800 & 900 & 1000 & 1200 & 1320 & 2050 & 1300 \\
\hline Shelburne & 44 & 23 & 71 & 5 & 700 & 700 & 700 & 800 & 860 & 3960 & 800 \\
\hline Somersworth & 43 & 15 & 70 & 53 & 70 & 80 & 120 & 270 & 280 & 300 & 250 \\
\hline South Hampton & 42 & 53 & 70 & 58 & 90 & 100 & 100 & 200 & 210 & 280 & 200 \\
\hline Springfield & 43 & 30 & 72 & 3 & 1020 & 1030 & 1030 & 1500 & 1560 & 2300 & 1500 \\
\hline Stark & 44 & 36 & 71 & 24 & 900 & 920 & 950 & 1200 & 1240 & 3730 & 1200 \\
\hline Stewartstown & 44 & 58 & 71 & 25 & 1000 & 1050 & 1050 & 2200 & 2600 & 2990 & 2000 \\
\hline Stoddard & 43 & 5 & 72 & 7 & 1250 & 1260 & 1300 & 1500 & 1760 & 2150 & 1600 \\
\hline Strafford & 43 & 17 & 71 & 9 & 250 & 260 & 280 & 860 & 1020 & 1400 & 800 \\
\hline
\end{tabular}

* To convert feet to meters, multiply by 0.305 . 


\begin{tabular}{|c|c|c|c|c|c|c|c|c|c|c|c|}
\hline Town & $\begin{array}{l}\text { Lati } \\
\text { (deg }\end{array}$ & $\begin{array}{l}\text { ude } \\
\min )\end{array}$ & $\begin{array}{l}\text { Long } \\
\text { (deg }\end{array}$ & $\begin{array}{l}\text { itude } \\
\text { min) }\end{array}$ & $\begin{array}{l}\text { Minimum } \\
\text { elevation } \\
(\mathrm{ft})^{*}\end{array}$ & $\begin{array}{c}\text { Minimum } \\
\text { building } \\
\text { elevation } \\
\text { (ft)* }\end{array}$ & $\begin{array}{c}\text { Low } \\
\text { elevation } \\
\text { limit of } \\
\text { most } \\
\text { buildings } \\
\text { (ft)* }^{*}\end{array}$ & $\begin{array}{c}\text { High } \\
\text { elevation } \\
\text { limit of } \\
\text { most } \\
\text { buildings } \\
\text { (ft)* }^{*}\end{array}$ & $\begin{array}{c}\text { Maximum } \\
\text { building } \\
\text { elevation } \\
\text { (ft)* }\end{array}$ & $\begin{array}{l}\text { Maximum } \\
\text { elevation } \\
(\mathrm{ft})^{*}\end{array}$ & $\begin{array}{c}\text { Case } \\
\text { study } \\
\text { elevation } \\
\text { (ft)* }\end{array}$ \\
\hline Stratford & 44 & 42 & 71 & 31 & 860 & 900 & 900 & 1100 & 1400 & 3600 & 1100 \\
\hline Stratham & 43 & 1 & 70 & 54 & 10 & 20 & 20 & 160 & 180 & 290 & 150 \\
\hline Success & 44 & 31 & 71 & 5 & 1220 & 1300 & 1300 & 1600 & 1600 & 3570 & 1600 \\
\hline Sugar Hill & 44 & 13 & 71 & 48 & 880 & 900 & 900 & 1600 & 1720 & 2080 & 1600 \\
\hline Sullivan & 43 & 1 & 72 & 13 & 810 & 1000 & 1060 & 1450 & 1470 & 1730 & 1400 \\
\hline Sunapee & 43 & 23 & 72 & 5 & 920 & 930 & 930 & 1440 & 1490 & 1590 & 1400 \\
\hline Surry & 43 & 2 & 72 & 20 & 490 & 530 & 530 & 1100 & 1220 & 1560 & 1100 \\
\hline Sutton & 43 & 20 & 71 & 56 & 450 & 480 & 550 & 1100 & 1560 & 1800 & 1100 \\
\hline Swanzey & 42 & 52 & 72 & 18 & 450 & 460 & 460 & 730 & 890 & 1410 & 800 \\
\hline Tamworth & 43 & 51 & 71 & 17 & 420 & 440 & 450 & 1100 & 1160 & 2690 & 1000 \\
\hline Temple & 42 & 50 & 71 & 52 & 800 & 820 & 850 & 1300 & 1300 & 2100 & 1300 \\
\hline $\begin{array}{l}\text { Thompson \& } \\
\text { Meserves Purchase }\end{array}$ & 44 & 18 & 71 & 17 & 1640 & 2570 & 2570 & 2720 & 2720 & 5910 & 2500 \\
\hline Thornton & 43 & 55 & 71 & 39 & 550 & 560 & 600 & 1160 & 1200 & 2600 & 1200 \\
\hline Tilton & 43 & 28 & 71 & 35 & 390 & 400 & 400 & 870 & 870 & 870 & 900 \\
\hline Troy & 42 & 50 & 72 & 12 & 730 & 1000 & 1000 & 1300 & 1390 & 1890 & 1300 \\
\hline Tuftonboro & 43 & 41 & 71 & 15 & 500 & 510 & 510 & 1100 & 1120 & 2920 & 1100 \\
\hline Unity & 43 & 18 & 72 & 16 & 550 & 550 & 690 & 1500 & 1700 & 2010 & 1500 \\
\hline Wakefield & 43 & 36 & 71 & 1 & 460 & 470 & 480 & 940 & 1020 & 1100 & 900 \\
\hline Walpole & 43 & 5 & 72 & 25 & 240 & 250 & 260 & 1380 & 1460 & 1650 & 1200 \\
\hline Warner & 43 & 17 & 71 & 49 & 380 & 400 & 400 & 800 & 1100 & 2000 & 800 \\
\hline Warren & 43 & 57 & 71 & 53 & 680 & 680 & 700 & 1300 & 1750 & 3300 & 1300 \\
\hline Washington & 43 & 11 & 72 & 5 & 870 & 900 & 910 & 1600 & 1700 & 2470 & 1700 \\
\hline Waterville Valley & 43 & 57 & 71 & 30 & 920 & 1440 & 1440 & 1880 & 3450 & 4120 & 1800 \\
\hline Weare & 43 & 5 & 71 & 43 & 300 & 310 & 350 & 850 & 960 & 1210 & 900 \\
\hline Webster & 43 & 18 & 71 & 43 & 380 & 380 & 400 & 700 & 780 & 860 & 700 \\
\hline Wentworth & 43 & 52 & 71 & 56 & 540 & 580 & 600 & 1400 & 1520 & 2600 & 1200 \\
\hline Wentworth Location & 44 & 51 & 71 & 8 & 1250 & 1260 & 1260 & 1280 & 1480 & 2940 & 1300 \\
\hline Westmoreland & 42 & 58 & 72 & 26 & 220 & 240 & 290 & 800 & 980 & 1510 & 800 \\
\hline Whitefield & 44 & 23 & 71 & 35 & 890 & 900 & 900 & 1380 & 1700 & 1710 & 1400 \\
\hline Wilmot & 43 & 27 & 71 & 55 & 640 & 660 & 680 & 1200 & 1400 & 2950 & 1200 \\
\hline Wilton & 42 & 50 & 71 & 46 & 350 & 350 & 350 & 950 & 960 & 1020 & 900 \\
\hline Winchester & 42 & 47 & 72 & 24 & 240 & 300 & 400 & 700 & 900 & 1420 & 700 \\
\hline Windham & 42 & 48 & 71 & 18 & 140 & 140 & 150 & 420 & 450 & 460 & 400 \\
\hline Windsor & 43 & 7 & 72 & 2 & 960 & 1060 & 1160 & 1250 & 1250 & 1610 & 1200 \\
\hline Wolfeboro & 43 & 37 & 71 & 10 & 500 & 510 & 510 & 1100 & 1220 & 1420 & 1000 \\
\hline Woodstock & 44 & 0 & 71 & 44 & 600 & 620 & 620 & 1840 & 2420 & 4170 & 1200 \\
\hline \multicolumn{12}{|c|}{ Summary statistics for each column of elevation information shown above. } \\
\hline Minimum value & & & & & 0 & 10 & 10 & 40 & 50 & 60 & 50 \\
\hline Median value & & & & & 480 & 480 & 490 & 1100 & 1240 & 1880 & 1000 \\
\hline Average value & & & & & 560 & 580 & 600 & 1070 & 1200 & 1950 & 1030 \\
\hline Maximum value & & & & & 2320 & 3970 & 3970 & 6290 & 6290 & 6290 & 2500 \\
\hline
\end{tabular}

* To convert feet to meters, multiply by 0.305 .

NA means there are essentially no buildings in this town. 


\section{APPENDIX B. GUIDELINES ON CONDUCTING CASE STUDIES}

The guidance below was provided at the beginning of this study of New Hampshire towns. As this report indicates, improvements have been made as a result of this study. Therefore, this initial guidance should be considered along with the improvements and alternative methods of analysis discussed in this report.

\section{Guidance on how to conduct snow load case studies}

\section{By Wayne Tobiasson and Alan Greatorex, CRREL}

This brief write-up should be used together with information in the conference paper "Database and Methodology for Conducting Site Specific Snow Load Case Studies for the United States" (Tobiasson and Greatorex, 1997). We suggest that you first read the conference paper for general information, then finish reading this brief write-up for additional information on the case study process.

Never put all your faith in results from a single station but do not completely dismiss any station because its values do not fit with others around it.

"Misfits" in 50-year mean recurrence interval values (i.e., $p_{\mathrm{g}}$ values) are often due to short periods of record. A 50 -year $p_{\mathrm{g}}$ based only on 10 or 15 years of record can be good or bad. Once 20 to 30 years of data are available, it is hard to dismiss that $p_{\mathrm{g}}$ as being a bad extrapolation from limited data. When a $p_{\mathrm{g}}$ is based on more than 30 years of data, give a lot of weight to it. However, if the $p_{\mathrm{g}}$ value of a station with more than 30 years of record is more than about 1.5 times the "Record Max" observed there, we give little weight to that $p_{\mathrm{g}}$. We have determined that a few very low annual maximums can cause a $p_{\mathrm{g}}$ value for a station to be higher than if those values are not considered. This is one of the limitations (in our judgment) of extreme value statistics, but we know of no other approach that produces as reliable design values across the board, so we live with it.

The plots do not give any consideration to years of record or distance from the site. When the plots do not point to a clear answer, we examine the tabulation and check off stations with long periods of record within 10 to 15 miles (16 to 24 $\mathrm{km}$ ) of the site. Then we highlight those stations on the "all stations" plot. By giving extra weight to them and "eyeballing" in a new "least squares" line, the answer may present itself. 
In most places, stations within a 10 or 15 mile (16 to $24 \mathrm{~km}$ ) radius are much more valuable than stations farther away. That is why we like to look at two plots. However, the "least squares" line on the "nearest 6" (or whatever) plot, since it contains just a few points, often has a slope that is less believable than the slope on the "all stations" plot. The slope of each "least squares" line is written near the legend (e.g., $2.43 \mathrm{lb} / \mathrm{ft}^{2}$ per $100 \mathrm{ft}$ ). Slopes of 2.0 to $3.0 \mathrm{lb} / \mathrm{ft}^{2}$ per $100 \mathrm{ft}$ $\left(0.31\right.$ to $0.47 \mathrm{kN} / \mathrm{m}^{2}$ per $\left.100 \mathrm{~m}\right)$ seem about right for northern New England. Sometimes it is valuable to set up the "all stations" slope or a slope of about 2.5 $\mathrm{lb} / \mathrm{ft}^{2} / 100 \mathrm{ft}\left(0.39 \mathrm{kN} / \mathrm{m}^{2}\right.$ per $\left.100 \mathrm{~m}\right)$, on the "nearest 6" plot and eyeball an answer using it.

One of us likes to consider snow belts, snow shadows, lake effects, weather patterns and such when he studies a site. The other does not feel he knows enough about such matters in each place to accurately consider such variables so he does not use this approach. Our different approaches are usually not the reason why we occasionally come up with different answers. We think it is valuable to arrive at our answers from different viewpoints. We urge independent analysis by two or more individuals instead of round table concurrent analysis by a team since group dynamics can adversely influence results in the latter setting. We recommend that groups only be used thereafter to resolve differences among individual answers. 


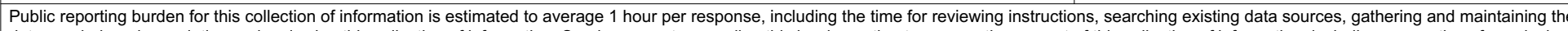

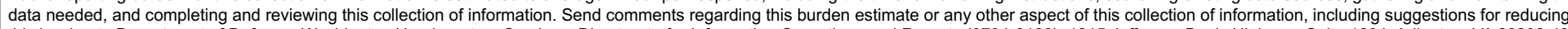

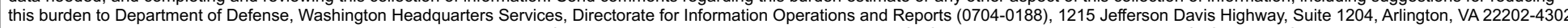

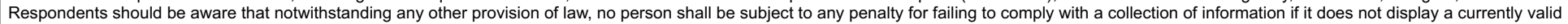
OMB control number. PLEASE DO NOT RETURN YOUR FORM TO THE ABOVE ADDRESS.
1. REPORT DATE (DD-MM-YY)
2. REPORT TYPE
February 2002
Technical Report
3. DATES COVERED (From - To)

4. TITLE AND SUBTITLE

5a. CONTRACT NUMBER

Ground Snow Loads for New Hampshire

5b. GRANT NUMBER

5c. PROGRAM ELEMENT NUMBER

\section{AUTHOR(S)}

Wayne Tobiasson, James Buska, Alan Greatorex, Jeff Tirey, Joel Fisher, and Steve Johnson

5d. PROJECT NUMBER
4A762784AT42

5e. TASK NUMBER

5f. WORK UNIT NUMBER

AT42-AP-001

7. PERFORMING ORGANIZATION NAME(S) AND ADDRESS(ES)

U.S. Army Engineer Research and Development Center

Cold Regions Research and Engineering Laboratory

72 Lyme Road

Hanover, New Hampshire 03755-1290

9. SPONSORING/MONITORING AGENCY NAME(S) AND ADDRESS(ES)

8. PERFORMING ORGANIZATION REPORT NUMBER

ERDC/CRREL TR-02-6

10. SPONSOR / MONITOR'S ACRONYM(S)

Office of the Chief of Engineers

Washington, DC 20314

\section{DISTRIBUTION / AVAILABILITY STATEMENT}

Approved for public release; distribution is unlimited.

Available from NTIS, Springfield, Virginia 22161.
11. SPONSOR / MONITOR'S REPORT NUMBER(S)

\section{ABSTRACT}

Because of New Hampshire's hilly landscape, mapped values of ground snow load are not available for much of its area. We conducted snow load case studies to establish ground snow loads for a specific elevation in each of the 259 towns in the state. That work was done by three researchers and three structural engineers practicing in New Hampshire. While our methods of analysis varied somewhat, our results were comparable and the feedback we received from each other was quite valuable. We also established a statewide elevation adjustment factor to transfer our snow load answers to other elevations in each town. We suggest that similar studies be conducted for other places in the United States where mapped values are not available because of extreme local variations in ground snow loads.

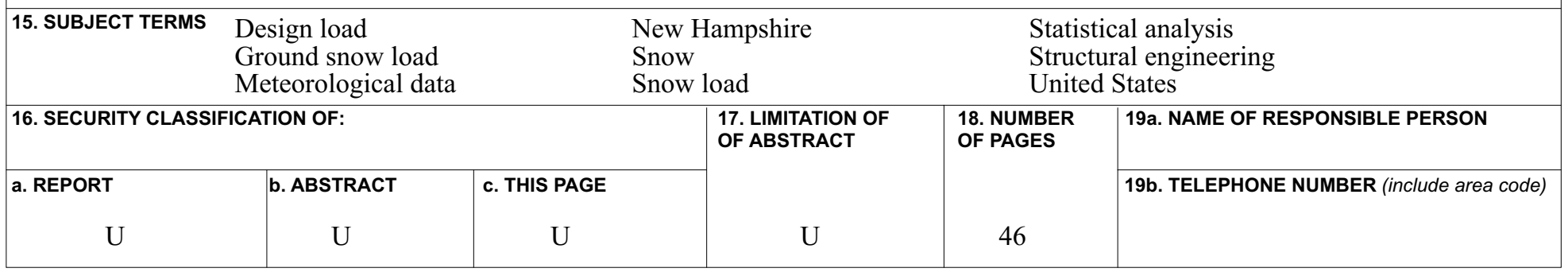




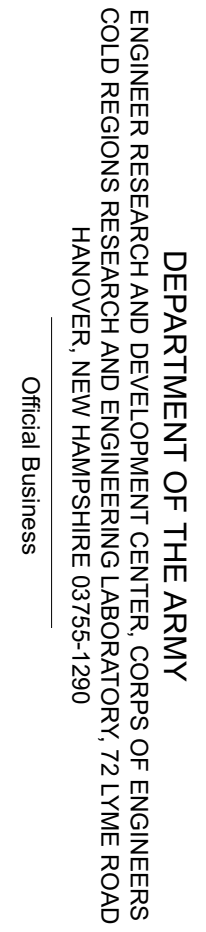

